Max-Planck-Institut für demografische Forschung

Max Planck Institute for Demographic Research

Konrad-Zuse-Strasse 1 - D-18057 Rostock · GERMANY

Tel +49 (0) 3812081 - 0; Fax +49 (0) 3812081 - 202;

http://www.demogr.mpg.de

MPIDR WORKING PAPER WP 2006-045

NOVEMBER 2006

\title{
Cohort birth order, parity progression ratio and parity distribution trends in developed countries
}

Tomas Frejka (frejka@demogr.mpg.de)

Jean-Paul Sardon

This working paper has been approved for release by: Jan M. Hoem (hoem@ demogr.mpg.de)

Head of the Laboratory of Contemporary European Fertility and Family Dynamics.

(C) Copyright is held by the authors.

Working papers of the Max Planck Institute for Demographic Research receive only limited review. Views or opinions expressed in working papers are attributable to the authors and do not necessarily reflect those of the Institute. 


\title{
Cohort Birth Order, Parity Progression Ratio and Parity Distribution Trends in Developed Countries
}

\author{
Tomas Frejka, Independent consultant (MPIDR, Rostock) \\ and \\ Jean-Paul Sardon, Institut National d'Études Démographiques, Paris
}

\begin{abstract}
This paper is the latest in a series initiated in 1999 which investigates childbearing in low fertility countries from a cohort perspective. Principal conclusions: Major changes in childbearing patterns are continuously taking place in almost all countries. Large families with four and more children have all but disappeared. Almost everywhere the two-child family became dominant. Proportions of childless women and of one-child families were increasing among recent cohorts. Childbearing postponement is a virtually universal process in contemporary low-fertility populations. In Central and Eastern European (CEE) countries, starting with the 1960s cohorts, changes in age patterns of childbearing have been profound which justifies labeling these as an historic transformation. One indisputable characteristic is that young women are bearing considerably fewer children compared to older cohorts. In particular, the proportions of women having second births in most CEE countries were declining rapidly and these proportions were lower than in western countries. Postponement of childbearing might be nearing cessation in some western countries.
\end{abstract}

\section{Introduction}

It is now well known that levels and trends in period total fertility rates can be inflated or deflated by the timing, postponement or anticipation, of childbearing (Hajnal 1947, Henry 1953, Ryder 1951, Whelpton 1954, Bongaarts and Feeney 1998).

For two to three decades in the middle of the $20^{\text {th }}$ century in western countries the quantum of fertility was increasing, and, in addition, period fertility was being augmented by a shift of childbearing into younger ages. This was the era of the "baby boom." In South European countries this process took place with a time lag of about a decade. At the same time, in Central and East European countries the quantum of fertility was stable coupled with only a moderate anticipation of childbearing.

Profoundly changing economic, social and cultural circumstances modifying fertility emerged in the 1960s in the industrialized western countries (Hobcraft and Kiernan 1995), which engendered a fertility quantum decline and started an enduring postponement of childbearing. Roughly analogous developments occurred in the South European countries, again with a one to two decades delay. In Central and East European countries the historical political events around 1990 which brought down the authoritarian regimes also entailed radical transformations in the economic, social and cultural environment conditioning family formation and fertility. As a result fertility quantum declined rapidly and apparently childbearing postponement was also taking root. Exceptionally moderate fertility reductions and delays started prior to the momentous political transitions.

In 1999 Calot, Frejka and Sardon started to work on a project investigating childbearing levels and trends in low fertility countries during the $20^{\text {th }}$ century from a cohort perspective. A preliminary report was published in the Population and Development Review (Frejka, Calot 
2001). Since then about a dozen papers were published, in 2004 a comprehensive report came out in book form (Frejka, Sardon 2004), and an update was presented at the 2005 IUSSP Conference (Frejka, Sardon 2005).

There are reasons to assume that a more thorough investigation than previously of childbearing levels and trends by birth order, of parity progression ratios and the resulting trends in parity distributions could shed some additional insights as well as provide a basis for judgments on whether the ongoing trends of fertility quantum decline and childbearing postponement will continue in the foreseeable future. A paper "First birth trends in developed countries: Persisting parenthood postponement" (Frejka, Sardon 2006) was published recently. The present paper continues in this exploration covering not only first, but also second, third, fourth and higher birth orders, cohort parity progression ratios and cohort parity distributions.

We begin with a brief section on data and a short summary of findings of the project to date. The next part discusses birth order levels and trends. We then continue with an investigation of the timing of childbearing by analyzing a variety of measures: (a) the cohort mean age of the respective birth order; (b) the crude age structure of the respective birth order in cohorts that have effectively completed their childbearing; (c) trends in cumulated rates of the respective birth order in older and young women. Finally, we turn to detailed analyses of age patterns of the respective birth order in cohorts that have completed childbearing and in cohorts that are still at various stages of their reproductive period; trends of parity progression ratios; and trends in parity distributions in specific countries.

Most of the analysis deals with cohorts that had already concluded their childbearing; the last such cohorts scrutinized tend to be those of the mid- to late 1960s. Thus the respective conclusions are relevant mainly with respect to the last decades of the $20^{\text {th }}$ century. -- There are sections in which the analysis deals exclusively or in part with young women, i.e. with women that had not yet reached the end of their reproductive periods. In these sections cohorts of the 1970s (up to and including the 1980 cohort) are included. This is important to keep in mind, because these are the cohorts whose childbearing behavior was reflected in the period fertility rates of the late 1990 s and the early $21^{\text {st }}$ century.

\section{The data}

In distinction to the overall project in which 35 low fertility country populations were part of the investigation, only 27 are analyzed in this paper; seven imperfectly representative populations are investigated in greater detail. These data were gathered at the Institut National d'Études Démographiques in Paris since the end of the 1970s and since 1996 by the Observatoire Démographique Européen, which was founded by Gérard Calot and of which Jean-Paul Sardon has been director in recent years.

The series of cohort fertility data for some countries end earlier than for others. The series for the United States that include data based on statistics for recent years are currently being prepared at the U. S. National Center for Health Statistics and will not be released until late in 2006. Therefore these series are shorter than for other countries. For instance, for the 1970 birth cohort age-specific fertility rates are available up to age 33 for the Czech Republic, Denmark, Hungary and the Netherlands, but only up to age 25 for the United States. For Greece and Romania these are available up to age 32; for England \& Wales up to age 30; and for Italy up to age 26. 
Wherever any data include estimated values these are based on calculations in which less than 5 percent of the respective measure is estimated. This is in contrast to the estimation criterion used earlier, namely 15 percent (cf. Frejka, Sardon 2004). -- Throughout most of the investigation rates of the second kind are used, i.e. the number of occurrences-births is related to all women of the respective age category, not only to those exposed to the risk of having a birth of a specific birth order. The logical exception are parity progression ratios, which are necessarily rates of the first kind.

\section{A summary of main findings of the project to date}

The analysis for the low-fertility countries presented in the book and in the IUSSP update (Frejka, Sardon 2004 and 2005) came to the following principal substantive conclusions. Childbearing has never been as low as at the outset of the 21 st century. In most countries, a moderate fertility decline is likely to continue during the first decade. A fertility increase in the foreseeable future is unlikely. Incipient signs of fertility plateaus are apparent. Rates of recuperation among older women are slowing down. A low fertility plateau might be reached in individual countries with completed cohort fertility as low as 1.3 or less and probably no higher than 2.0 births per woman. The analysis implies that increases of total period fertility rates, including those of adjusted TFRs, in most countries are not a reflection of increases in cohort childbearing, but a result of lesser postponement of births.

Levels and trends of various facets concerning first births are continuously changing (Frejka, Sardon 2006). The evidence confirms that the postponement of first births is an ongoing and persisting process which started in western countries among cohorts of the 1940s, but only in the 1960s cohorts in Central and Eastern Europe. The mean age of women having first births is universally rising. Fertility of older women was increasing. The decline in childbearing of young women is robust among the cohorts of the late 1960s and the 1970s; in Southern Europe as well as in Central and Eastern Europe the rates of decline have accelerated. Childbearing behavior in the formerly socialist countries is in transition to a different regime.

As stated above, the present paper aims to investigate in greater detail developments regarding all birth orders, trends of birth order levels, changes in the timing of birth orders, parity progression ratios and parity distributions.

\section{Birth order levels and trends}

The most prevalent feature of trends in cohort fertility in the developed countries of any birth order is decline among the cohorts born during the 1960s, i.e. those ending their reproductive careers early in the $21^{\text {st }}$ century. In some countries and at some birth orders a leveling off has occurred, but not a single case of notable increase has taken place.

\section{First births}

Long-term regional trends were evident in the levels and trends of first births (Figure 1). Most western countries experienced increases in the first birth TCFRs among cohorts of the 1920s and 1930s. These reached a peak among the 1940s cohorts and from thereon started to decline. The United States population was about a decade ahead of the general trend.

In contrast, first birth TCFRs in Central and East European countries were high and stable from the cohorts of the 1930s through those of around 1960, with a considerable decline thereafter. 
A smaller amount of data for the Nordic and South European countries also indicate regional similarities between countries, albeit less pronounced.

In the 1960s birth cohorts in most countries between 83 and 90 percent of women had a first birth (Figure 1 and Table 1). In some countries the proportions were as low as 80 percent, implying that around 20 percent were remaining childless. Exceptionally around 95 percent of women had first births with only about five percent remaining childless ${ }^{1}$.

In practically all the South, Central and East European countries first birth TCFRs were declining quite rapidly among the 1960 s cohorts. A moderate first birth TCFR descent was also taking place in Finland, Austria and England \& Wales. In most Nordic countries, the Netherlands and the United States, the first birth TCFRs were quite stable (Figure 1).

\section{$\underline{\text { Second births }}$}

Certain characteristic regional features are discernible also in the long-term second birth TCFRs trends (Figure 2 and Table 1): near stability in the Nordic countries; a gradual decline in most western countries; relative stability turning into a rapid decline in the Central and East European countries; and South European countries experiencing reasonable stability followed by descent.

Differences in the levels of second birth TCFRs among the 1960s cohorts were quite considerable, ranging from below 0.55 in Romania to 0.73 in Norway (Figure 2).

In the western countries between 64 and 73 percent of women were having second births. In Norway and Sweden rates were stable, and in Denmark and the US even a slight increase was under way. In Finland, the Netherlands and England \& Wales rates were declining moderately. Austria's second birth TCFR in the 1960s cohorts was exceptionally low - only 57 percent of women were having second births.

There was a wide difference in the second birth TCFR among the formerly socialist countries of Central and Eastern Europe. For the latest available cohorts of the 1960s the values ranged from less than 0.55 in Romania to around 0.70 in the Czech Republic. Two features stand out in contrast to the western countries. The proportions of women having second births were declining rapidly and in most countries these proportions were reaching levels that were lower than in the western countries, i.e. around 0.65 second births per woman (Figure 2).

In the South European countries second birth TCFRs were between 0.60 and 0.65 among the 1960s cohorts; in Greece it was higher, 0.67 second birth per woman. These rates were declining moderately.

\section{Third births}

The differential regional features persisted among long-term third birth TCFR trends (Figure 3).

\footnotetext{
${ }^{1}$ The first birth TCFRs around and above 0.95 births per woman in Portugal are likely to be the consequence of registration errors.
} 
In the western countries between 20 and 30 percent of women were bearing third children. Starting with the cohorts of the late 1940s these rates have apparently stabilized.

In the Central and East European countries third birth TCFRs were also in the 0.20 to 0.30 range in the 1960 s birth cohorts. Most countries experienced a long-term decline which was still continuing among the 1960s cohorts. The trend in Hungary was not typical, third order births even increased among the cohorts of the late $1950 \mathrm{~s}$, from 0.20 to 0.24 births per woman.

In all South European countries third birth TCFRs were below 0.20 among the 1960s cohorts and the long-term decline still appeared to be in progress.

\section{Fourth and higher order births}

Fourth and higher order births TCFRs ranged from 0.05 to 0.25 births per woman among the cohorts of the early 1960s in the countries for which data are available (Figure 4 and Table 1).

Following a long-term decline the fourth and higher order births TCFRs had stabilized among the 1950 s cohorts in the western countries within the 0.10 to 0.20 range (Figure 4 ). A minor increase did occur in some countries, for instance, in Sweden.

In the Central and East European countries there was a relatively wide range of fourth and higher order TCFRs among the early 1960s cohorts from 0.07 in the Czech Republic to 0.25 in Romania. In some countries a moderate decline was still under way. In Hungary and Poland these TCFRs were stabilizing among the late 1950s cohorts; in the latter at a relatively high level of 0.22 births per woman.

In the South European countries the fourth and higher order births TCFRs were all below 0.10 among the cohorts of the late 1950s and early 1960s. And a moderate decline still appeared to be continuing.

\section{Cohort mean ages of birth orders}

The cohort mean ages of the birth orders inform on whether these occur early or late, and the trends are a crude indication of whether fertility is being advanced or postponed (Table 2 and Figure 5).

A decline in the cohort mean age of childbearing in all birth orders among cohorts of the 1920s and 1930s which then transformed into an increase among cohorts of the 1950s and 1960s was the overriding long-term trend in most countries. In the Central and East European countries the cohort mean ages of childbearing were relatively stable from the 1930s to the 1950 s cohorts and started a gradual increase among the 1960s cohorts.

In the cohorts of the 1960s cohort mean ages of first births ranged from 23 to 29 years of age; second birth mean ages from 25 to 31; third birth mean ages from 26 to 32; and fourth and higher birth order mean ages from 29 to 34 .

More specifically, mean ages of the first, second and third birth orders in most countries for recent 10 to 20 cohorts, namely the birth cohorts of the 1950s and 1960s, were rising. This is an indication that childbearing in these birth orders were being postponed. 
Exceptionally third birth mean ages were stable among recent birth cohorts, for instance, in Denmark, Hungary and the United States. Stability in the mean ages of fourth and higher birth orders among recent cohorts was the rule. These were not being postponed (Figure 5).

\section{The age structure of birth orders}

A complementary crude device to assess the timing of childbearing is to analyze changes in the age structure of women having births of the respective birth orders (Table 3 ). The measure applied in this project is the proportion of births borne by "young" women (defined as prior to the $27^{\text {th }}$ birthday). A rise in this proportion implies anticipation of births, a decline indicates childbearing postponement ${ }^{2}$.

In all birth orders countries differ from each other considerably as to the basic timing of births. One of the clearly distinct differences in childbearing patterns during most of the second half of the $20^{\text {th }}$ century between western and formerly socialist countries was late childbearing in the former and early childbearing in the latter. In the Central and East European countries among the 1960s cohorts close to 90 percent of first births were borne by young women, whereas in western and South European countries these proportions were between 40 and 70 percent. The differences were of similar orders of magnitude for second and third order births.

While there were large differences in proportions of young women bearing children, trends in time went in similar directions. Among the cohorts of the 1930s and often also of the 1940s the proportions tended to increase. For the more recent birth cohorts the proportion of young women bearing children has been declining across the board practically in all countries and for most birth orders (Table 3). Among the cohorts that have effectively concluded their childbearing, the 1960s cohorts covered in Table 3, the declines were faster among the western countries than among the formerly socialist ones. This is understandable as major parts of the reproductive life in the latter countries took place under the old communist regimes.

\section{Fertility of older women}

Table 4 provides information about the absolute levels and trends of childbearing of older women by birth order.

In the western countries the levels of fertility of all birth orders after age 27 were high, considerably higher than in Central and Eastern Europe. Not surprisingly, the levels of second births were universally higher than those of first births. For instance, in the 1965 cohort between 0.4 and 0.5 of a first order child was borne by older women in Denmark and the Netherlands, and over 0.5 of second order children. The corresponding values for first order children in the Czech Republic, Hungary and Romania were 0.1 for first order births and 0.1 0.3 for second order births.

For the most part, there was an impressive increase of first births among older women. In western countries this took place starting with the 1940 cohorts, in Central and Eastern Europe the increase commenced in the early 1960s cohorts.

\footnotetext{
${ }^{2}$ A change in the age structure is indeed a crude device, because disproportional declines or increases in fertility at certain ages could cause a change in the age structure without any changes in timing. For instance, a fertility decline exclusively among older women will cause a change in the age structure of childbearing that has nothing to do with timing.
} 
In the 1950s and 1960s cohorts there was also a measurable increase in second order births among older women in the West, but not in the Central and East European countries.

\section{Fertility of young women}

So far we have dealt exclusively with cohorts that have effectively completed their childbearing. The fertility patterns of cohorts that are in various stages of incomplete childbearing can also provide useful insights, among others, because one can analyze the fertility behavior of more recent, younger cohorts. The main contribution of such an exploration is to gain an understanding of the childbearing behavior of women of various ages that are shaping contemporary fertility.

There is a considerable variety in the levels of fertility between countries, particularly among first order births of young women. In the early 1970 s cohorts these were around 0.3 births per woman in South European countries, 0.3 to 0.4 in western countries and 0.5 to 0.6 in countries of Central and Eastern Europe (Table 5).

Second order births in the mid 1970 cohorts were also the highest in the Central and East European countries, around or above 0.2 births per woman. In the other countries these rates were closer to 0.1 births per woman. - Third order births were rare among young women, usually not above 0.05 births per woman.

Two features stand out regarding trends:

1. Childbearing of all birth orders of young women has been declining persistently for a considerable sequence of cohorts. The decline started among the cohorts of the 1940s in the western countries, the 1950s cohorts in Southern Europe, and the 1960s cohorts in Central and Eastern Europe.

2. The decline has been more robust among the more recent cohorts born in the 1960 s and the early 1970 s.

These trends reflect a combination of fertility quantum decline and childbearing postponement. As these trends concern cohorts that are in the midst of their childbearing periods, the relative weight of these two effects cannot be singled out.

\section{Birth order trends, parity progression and parity distribution in selected countries}

A more profound understanding of birth order trends and of the nature of their timing can be gained by studying detailed changes of age patterns of fertility measured by single year age-specific fertility rates in individual countries. In addition, cohort parity progression ratios and cohort parity distribution will be explored in selected countries.

\section{Denmark}

Among the cohorts of the 1950s and 1960s between 87 and 90 percent of women in Denmark were having first births, 68 to 70 percent second births and between 22 and 27 percent were having third births (Table 1, Figures 1-3 and 7).

Developments in childbearing postponement by birth order are depicted in Figure 6. First order births were being postponed from one cohort to the next. Each successive curve is 
shifted more to the right into the higher ages with fertility at lower ages declining and at higher ages increasing. The peak of childbearing was shifting from age 23 in the 1950 cohort to age 26 in the 1970 cohort.

Among second order births there was a considerable postponement of childbearing between the 1950 and the 1960 cohorts. The peak of childbearing between these two cohorts shifted from age 24 to 29. Postponement of second births was continuing among the cohorts of the 1960s and 1970s, but at a slower pace and the peak of the childbearing pattern shifted only by one year from the 1960 to the 1970 cohort.

Among third order births fertility was quite low, nevertheless childbearing postponement was taking place between the 1950 and the 1960 cohorts. Among the subsequent cohorts of the 1960s, while there had been a moderate rise in third order births, these were not being postponed further. - The incidence of fourth order births among cohorts of the 1950s and early 1960s was very low and very little if any changes in timing were taking place.

For the cohorts for which data are available parity progression ratios (PPRs) are reasonably stable: for first births close to 90 percent and slightly less than 80 percent of women progressed to a second birth (Figure 8 and Table 6). A slight increasing tendency could be detected in the 1950s and early 1960s cohorts with around 35 percent of women with second births having a third one, and close to 25 percent of 3-parity women having a fourth birth.

The parity distribution was also quite stable (Figure 9 and Table 7). In the cohorts of the early 1960s around 45 percent of women had two children, roughly equal proportions of almost 20 percent had one or three children; around 12 percent remained childless and families ${ }^{3}$ with 4 or more children were very rare.

\section{England \& Wales}

In England \& Wales the total cohort fertility rates for all birth orders had been declining since the cohorts of the mid-1940s (Table 1 and Figures 1-4 and 7). The proportions of women having a first birth declined from 90 percent in the cohorts of the mid 1940s to 80 percent in the mid-1960s cohorts (Figure 7). The proportions having second children dropped from 75 percent to 67 percent. - Third, fourth and fifth order births experienced a considerable decline in the late 1930s and early 1940s cohorts and thereafter the descent was moderate.

Starting with the cohorts of the 1940s a continuous postponement of childbearing has occurred in all birth orders (Figure 10). The basic feature of childbearing postponement is maintained, namely that fertility at younger ages is declining from one cohort to the next and increasing at older ages among successive cohorts. However the age trajectory of fertility is distinct compared to most other countries. Age peaks of childbearing have practically disappeared among women in their twenties. Age-specific fertility rates tend to be at more or less even level and thus the curves are almost flat.

Parity progression rates to parity one (PPR0) declined starting with the cohorts of the 1940s (Figure 8, Table 6). At the same time the progression to second births following a rise among the cohorts of the 1920s and 1930s remained stable around 85 percent. The progression ratios to third and fourth parity births declined sharply among the 1930s and early 1940s cohorts. Since the cohorts of the mid-1940s, only slightly more than 40 percent of 2-parity

\footnotetext{
${ }^{3}$ The expressions "family" and "parity" are often used interchangeably even though this is not accurate.
} 
women went on to have a third birth and around 35 percent of 3-parity women had a fourth birth.

As a result of the PPR trends there was a considerable rise in two children families to over 40 percent in the mid-1940s cohorts with a moderate decline thereafter (Figure 9, Table 7). The other prominent trend was an increase in childless women from about 10 to 20 percent.

\section{Netherlands}

In the Netherlands first and second birth order TCFRs were quite similar to those in England \& Wales (Table 1, Figures 1-4 and 7). Close to 90 percent of women were having first births in the mid-1940s cohorts and this proportion declined steadily to 82 percent in the cohorts of the mid-1960s. Almost 80 percent of women had second births in the cohorts born around 1940 which declined to 65 percent in the mid-1960s cohorts. A precipitous decline occurred in third and higher order births between the mid-1930s and mid-1940s cohorts which remained quite stable after that (Figure 7).

Postponement of childbearing was in progress from the cohorts of around 1940 to those of around 1970 in all birth orders, and has apparently come to a halt, at least as far as data are available, among the cohorts of the 1970s (Figure 11). The peak age of childbearing in first births was at age 24 in the 1940 cohort and has shifted to age 29 in the 1970 cohort. Among second births the peak age of childbearing went from age 25 to age 32 in the same cohorts. In third births the curve of age-specific fertility rates has also been shifting continuously to the right up to the 1970 cohort, even though at a relatively low level. That childbearing postponement appears to have ceased among the 1970s cohorts is evident from the fact that age-specific fertility patterns have not been changing from one cohort to the next. The trajectories of the curves overlap. This is the case for all birth orders.

The parity progression ratio to first births was at close to 90 percent in the cohorts of the 1930s and declined to 82 percent in the mid-1960s cohorts (Figure 8, Table 6). Progression to the second birth has been declining gradually from 88 in the 1940 cohort to 78 percent in the cohorts of the mid-1960s. Precipitous declines occurred in the PPRs to third and fourth order births from the cohorts of the 1920s to those of the late 1940s. PPRs to third births recovered somewhat in the 1950s cohorts and then resumed a moderate descent. The decrease of the progression to fourth births paused among the early 1950s cohorts, but thereafter continued.

The substantial changes in fertility behavior resulted in major changes of the parity distribution (Figure 9, Table 7). There was a large increase in the proportion of two child families -- in the 1945 birth cohort these amounted to one half of the total. On the other hand, the share of families with four or more children dropped from 30 percent in the 1925 cohort to five percent in the mid-1940s cohorts and has remained at that level. Starting with the cohorts around 1940 the proportions of childless women and of one-child families increased, each from around 10 to 18 percent in the mid-1960s cohorts.

\section{Italy}

A moderate decline in the proportions of women having first births in Italy occurred between the cohorts of the early 1950s and those around 1960 from 88 to 84 percent, respectively (Figure 7). There has also been a moderate and continuing descent in the TCFRs of second births which started with the cohorts of the late 1940s. Gradual and consequential long-term declines took place among third and higher birth orders. 
Unfortunately our time series of data for Italy are shorter than for other countries, nevertheless the detailed age-specific fertility patterns for successive cohorts of all birth orders demonstrate a persistent process of childbearing postponement (Figure 12). Among the cohorts of the 1940s childbearing was being advanced, but starting with the 1950s cohorts there was a consistent and persistent postponement of fertility in all birth orders. For the more recent cohorts it is only clear that fertility was declining at younger ages and it remains to be seen to what extent this is a sign of quantum decline rather than childbearing postponement.

It is also obvious that progression ratios have been on the decline for all birth orders (Figure 8, Table 6); less so to first births than to second and especially third and fourth order births. As far as data reach, these declines appeared to be continuing.

The two-child family was the most prevalent, over 40 percent of the total (Figure 9, Table 7). One-child families represented a larger share than in many other countries - close to a quarter in the cohorts of the mid-1950s. Also the proportion of childless women was increasing and larger families of four and more children all but disappeared.

\section{Czech Republic}

The proportion of women with a first birth was stable at 93 - 94 percent from the cohorts of the 1930s to the mid-1960s cohorts (Table 1, Figures 1 and 7). A moderate decline started among the cohorts of the late 1960s. It is estimated that about 90 percent of women in the 1970 cohort had a first child. -- Second birth TCFRs started a slow descent in the 1950s cohorts from 0.8 births per woman to about 0.7 in the 1970 cohort. The third and higher birth TCFRs were declining moderately from the 1920s cohorts onwards.

Throughout Central and Eastern Europe the demise of the authoritarian centrally planned political, economic and social system around 1990 had a dramatic effect on fertility behavior. It was particularly evident in changes of childbearing age patterns. These hardly changed for first order births through the mid-1960s cohorts. In reality a minor advancement of fertility was taking place among the cohorts of the 1940s and 1950s, but this cannot be discerned in Figure 13. A radical change started in the life-time strategies of childbearing among the cohorts of the mid-1960s. Between the ages of 22 and 25, fertility was distinctly lower in the 1970 compared to the 1965 cohort, whereas after age 27 available data exhibited much higher fertility in the 1970 cohort - between the ages of 32 and 35 childbearing almost doubled, albeit at low levels.

Rapid changes in the age patterns of first birth childbearing took shape among the cohorts of the 1970s (Figure 13). At peak childbearing ages, $19-21$, fertility dropped by one half between the 1970 and the 1975 cohorts, and by again as much between the next five cohorts. Evidently a significant part of this decline in early childbearing in the 1975 cohort was being postponed - first birth fertility after age 24 was markedly higher in the 1975 compared to the 1970 cohort. The shape of the 1980 age-specific fertility curve also implies childbearing postponement. Since these cohorts were still in the midst of childbearing it is not yet possible to determine the respective importance of quantum decline and postponement.

Changes in the age patterns of second birth fertility were a little more complex, but essentially went in similar directions: a slight advancement of fertility among the cohorts of the 1940s and 1950s, this turned to childbearing postponement among the 1960s cohorts, and radical changes ensued among the 1970s cohorts (Figure 13). For instance, in the 1950 and 
1960 cohorts by their $27^{\text {th }}$ birthday Czech women had had almost 0.6 second births, whereas in the 1975 cohort it was merely 0.2 births per woman (Table 5).

Among third and fourth order births there was no tendency to advance births in the older cohorts, but declines of fertility at younger ages and the postponement of fertility were strong among the cohorts of the late 1960s and the 1970s cohorts. But the level of fertility of the higher order births was so low that the effect on the overall situation is negligible and is difficult to discern in Figure 13.

Parity progression ratios to the first birth remained high at around 93 percent with a moderate decline starting in the mid-1960s cohorts (Figure 8, Table 6). The progression to second births increased among the 1930s and 1940s cohorts, remained steady at 85 percent among the 1950s cohorts, but then declined to below 80 percent in the cohorts of the 1960s. Progression to third and fourth births experienced gradual descents; in the 1960s cohorts about a quarter of women with two children go on to have a third one and of these again one quarter have a fourth child.

The proportion of families with two children was increasing steadily through the cohorts of the mid 1950s when they reached 55 percent, a share higher than in any other population (Figure 9, Table 7). This proportion started a moderate decline among the cohorts of the 1960s mainly at the expense of families with one child which were approaching one fifth of the total. Three child families held steady at about one fifth for many cohorts but were declining since the early 1950s cohorts. Families with four or more children were slowly disappearing and childless women were rare, although on a mild ascent in the 1960s cohorts.

\section{Romania}

Close to 95 percent of women had first births in the early 1950s cohorts; this proportion gradually declined to 86 percent in the 1970 cohort (Table 1, Figures 1 and 7). The decline in the proportions of women having second births was much faster, from over 70 percent in the 1950 cohort to around 50 percent in the cohorts of the late 1960s. There were also considerable declines in women with third and higher order births.

The demise of the authoritarian political, economic and social system and the transition to a democratic society and market based economy in the early 1990s fundamentally affected childbearing behavior. The age patterns of first birth childbearing hardly changed in the cohorts of the 1950s and early 1960s (Figure 14). A noticeable postponement of childbearing took place in the cohorts of the late 1960s. This was followed by a momentous decline in first order births among young women in cohorts of the 1970s. The peak age of first birth agespecific fertility remained at age 20 for all cohorts, however, the fertility rate at that age in the 1980 cohort was significantly less than half of its value in the 1965 cohort. At the same time, it is too early to establish whether this is primarily a quantum decline or a postponement of childbearing.

Among second order births the decline of peak fertility was even more pronounced (Figure 14). For instance, at age 22 the rate in the 1980 cohort, the last ASFR available for this cohort, was 65 percent below that of the 1965 cohort. Also the age trajectory of childbearing in the 1970 and 1975 cohorts was considerably lower than in the cohorts of the 1950s or early 1960s, and the curves of the 1970s cohorts did not indicate strong childbearing postponement. 
A significant decline in the age pattern of third and fourth birth childbearing is obvious in the 1965 cohort starting at ages $23-24$ (Figure 14). In the 1970s cohorts the curves for third and fourth order births flattened out at very low levels.

Declines in parity progression rates were under way already in the 1950 s cohorts (Figure 8, Table 6). The descent was especially rapid for progression to second order births in the 1960s cohorts. The considerable declines in the age patterns of fertility among the cohorts in the midst of their childbearing, the 1970s cohorts, imply that the drop in progression ratios will continue in the near future.

Extraordinary changes were occurring in the parity distribution (Figure 9, Table 7). The proportions of two-child families were relatively small - these fluctuated between 36 and 39 percent. Most unusual was the trend in the proportion of one-child families - this was increasing moderately among the 1950 s cohorts and then grew at an unusually rapid pace among the 1960s cohorts. In the late-1960s cohorts the proportion of the one child families was around 35 percent. Also the proportion of childless women was increasing - from six percent in the 1950 cohort to almost 15 percent in the cohorts born around 1970.

\section{United States}

Compared to other western countries trends in the levels of birth orders in the United States were more pronounced (Table 1, Figures 1-4 and 7). Total cohort fertility rates of all birth orders were increasing among the cohorts born early in the $20^{\text {th }}$ century to a peak in the principal baby boom cohorts of the 1930s. Thereafter they declined with increasing velocity from the first to higher order births. They settled down among the cohorts of the mid-1950s and were quite stable as far as the data reach. In the cohorts born around 196085 percent of women were having first births, more than 65 percent had second births and over 30 percent had third births. Women with fourth births amounted to less than 10 percent, and fifth and higher order births constituted less than five percent of all women.

Changes in age patterns of childbearing were also somewhat different in the United States compared to other western countries (Figure 15). The significant overall fertility declines among the 1940s cohorts were accompanied with an uncommon pattern of fertility postponement, especially among first births. While fertility was declining at young ages from the 1940 to the 1965 cohort, the peak age did not move to higher ages but remained at 19-20. Also, fertility at older ages was increasing. Among the cohorts of the late 1960s and early 1970s, as far as the data reach, there was very little movement in the age pattern of first birth childbearing.

In second birth age patterns of childbearing the peak age did shift between the 1940 and 1960 cohorts from age 22 to 24, fertility declined in the younger ages and increased after age 27. Starting with the 1960 cohort any changes were negligible. - Third birth age patterns of childbearing changed significantly among the cohorts of the 1940s: a major decline of fertility up to age 30 and a minor increase after age 30. Starting with the 1950 cohort age patterns of childbearing settled down and from thereon they hardly changed at all. - Similarly among fourth order births there was a considerable decline of fertility up to age 34 between the 1940 and the 1950 cohorts. Hardly any changes in age patterns occurred in subsequent cohorts. The curves were relatively flat at low levels.

Progression ratios to first births were above 90 percent in the 1930s cohorts, declined among the 1940s cohorts and settled at 84 percent in the 1950s cohorts (Figure 8, Table 6). 
Progression to second births was at its highest among the early 1930s cohorts, almost 90 percent. It declined to below 80 percent in the 1950s cohorts when it was stable. Progression ratios to third births declined steeply from 73 percent in the 1935 cohort to 47 percent in the 1950 cohort. Progression to fourth birth experienced a similarly rapid decline from 65 percent in the early 1960s cohorts to 37 percent in the 1955 cohort.

Trends in the parity distribution were likewise extraordinary (Figure 9, Table 7). After reaching a zenith of 38 percent among the mid-1930s cohorts, the proportion of the four-andmore children family declined rapidly reaching 14 percent in the 1950 cohort and continued to slide thereafter. The two child family took its place, but its ascent was slow from 35 percent in the 1935 cohort to 37 percent in the 1947 cohort. The proportions of the one child family and of childless women were also increasing among cohorts of the 1940s. Following these large shifts in family size the parity distribution was quite stable except for a continuous moderate increase in the three child family, mainly at the expense of larger families.

\section{Findings and Conclusions}

The volume of data scrutinized, studied and analyzed was huge and at times may seem overwhelming. Furthermore, it is obvious that major changes in childbearing patterns are continuously taking place in almost all countries. Among the conclusions that stand out are the following.

- There has been a considerable transformation of the parity distribution, i.e. in the size composition of families, between the cohorts born in the 1930s and the 1960s. Large families with four and more children have all but disappeared. In most countries there has been a considerable increase in the two-child family which became dominant. From a third to over a half of all families were in the two-child category in the 1960s cohorts. This might very well change in the near future. The proportions of childless women and of one-child families were increasing among recent cohorts and there are indications that these trends are continuing. What might seem surprising is that, at least up to the 1960s cohorts, the proportions of three-child families were relatively stable. Quite consistently, the three-child family tended to constitute about one fifth of the total.

- Childbearing postponement is a universal process in contemporary low-fertility populations. This process is ongoing and has not yet run its course in most countries. It has different forms. It has been taking place since the cohorts of the 1940s in North and West European countries and the United States, since the 1950s cohorts in Southern Europe and started with the 1960s cohorts in Central and Eastern Europe.

- In Central and Eastern European countries, starting with the 1960s birth cohorts, for the most part following the demise of the authoritarian centrally planned political, economic and social system around 1990, changes in the age patterns of childbearing have been so profound that it is justified to label these as an historic transformation. New and very different age patterns of fertility are in the making and it is not yet clear what the outcome will be. One indisputable new characteristic is that young women are bearing considerably fewer children compared to older cohorts. It is, however, too early to ascertain what proportion of the foregone children will be born when these women will be older. For the time being, it appears that there is a relatively weak rate of recuperation. 
- Particular developments in birth order trends provide important insights with regard to understanding recent low fertility levels in Central and Eastern Europe as well as in Southern Europe. In particular, the proportions of women having second births were declining rapidly and in most countries these proportions were lower than in western countries. There was also a continuing decline in proportions of women with third order births in the 1960s cohorts in CEE. In Southern Europe the proportions of third and fourth order births were comparatively low and continued to decline.

- Postponement of childbearing might be nearing its cessation in some countries. It appears that changes in the age patterns of childbearing have ceased starting with the cohorts of the late 1960s in the United States, and with the cohorts of the 1970s in the Netherlands.

Underlying these main findings are other conclusions that are discussed and outlined in the individual sections of the paper, the levels and trends in the birth order total cohort fertility rates, trends in the mean ages of childbearing, trends in the crude age composition of childbearing and trends in parity progression ratios.

\section{Acknowledgements}

The authors would like to acknowledge the Max Planck Institute for Demographic Research and the Institut National d'Études Démographiques for sponsoring the research, the Observatoire Démographique Européen for permission to use its demographic database, and Robert Krohn (MPIDR, Rostock) for computing assistance.

\section{References}

Bongaarts, John and Griffith Feeney, 1998, "On the quantum and tempo of fertility," Population and Development Review 24 (2): 271-291.

Frejka, Tomas and Gérard Calot. 2001. "Cohort reproductive patterns in low-fertility countries," Population and Development Review, 27 (1): 103-132.

Frejka, Tomas, and Jean-Paul Sardon. 2004. Childbearing Trends and Prospects in LowFertility countries: A cohort analysis, Dorbrecht: Kluwer Academic Publishers, 2004.

---------. 2005. "The direction of contemporary fertility trends in the developed countries: Further decline, plateau or upswing?" Proceedings of the XXV IUSSP International Conference, Tours, France.

---------. 2006. "First birth trends in developed countries: A cohort analysis," Max Planck Institute for Demographic research Working Paper, WP-2006-14

Hajnal, John. 1947. "The analysis of birth statistics in the light of recent international recovery of the birth-rate," Population Studies 1 (2): 137-164.

Henry, Louis. 1953. Fécondité des mariages. Nouvelle méthode de mesure. Travaux et Documents, Cahier n ${ }^{\circ} 16$, INED-PUF.

Hobcraft, J. and K. Kiernan, 1995, "Becoming a Parent in Europe," Evolution or Revolution in European Population, Proceedings of the European Population Conference, Milano.

Ryder, Norman B. 1951. The Cohort Approach. Ph. D. Dissertation. Princeton University. New York: Arno Press, 1980.

Whelpton. Pascal K. 1954. Cohort Fertility: Native White Women in the United States. Princeton, N.J.: Princeton University Press. 
Table 1 - First, second, third, fourth and higher birth order total cohort fertility rates, selected low fertility countries, birth cohorts 1930, 1940, 1950, 1960 and the latest available (see notes)

\begin{tabular}{|c|c|c|c|c|c|c|c|c|c|c|c|}
\hline \multirow[b]{2}{*}{ Country } & \multicolumn{6}{|c|}{ Total cohort fertility rates of cohort born in } & \multicolumn{5}{|c|}{$\begin{array}{l}\text { Annual change between birth } \\
\text { cohorts (percent) }\end{array}$} \\
\hline & 1930 & 1940 & 1950 & 1960 & 1965 & $\begin{array}{c}\text { Latest } \\
\text { availa } \\
\text { ble }\end{array}$ & $\begin{array}{l}1930- \\
1940\end{array}$ & $\begin{array}{l}1940- \\
1950\end{array}$ & $1950-$ & $\begin{array}{l}1960- \\
1965\end{array}$ & $\begin{array}{l}\text { 1965- } \\
\text { latest }\end{array}$ \\
\hline First & & & & & & & & & & & \\
\hline & & & & 0.899 & 0.873 & 0.8781 & $\cdots$ & $\cdots$ & $\cdots$ & -0.6 & 0.2 \\
\hline Engl & 0.870 & 0.893 & 0.861 & 0.811 & & $0.796 \mathrm{~h}$ & 0.3 & -0.4 & -0.6 & . & -0.5 \\
\hline Neth & . & 0.888 & 0.854 & 0.824 & 0.817 & $0.816 \mathrm{k}$ & $\ldots$ & -0.4 & -0.4 & -0.2 & -0.1 \\
\hline Greece & $\ldots$ & $\ldots$ & 0.903 & 0.894 & 0.834 & $0.834 \mathrm{j}$ & $\ldots$ & $\ldots$ & -0.1 & -1.4 & -0.1 \\
\hline Italy & $\ldots$ & 0.854 & 0.870 & 0.849 & & $0.849 \mathrm{~d}$ & $\ldots$ & 0.2 & -0.2 & $\ldots$ & $\ldots$ \\
\hline Czec & $\ldots$ & 0.923 & 0.933 & 0.936 & 0.929 & $0.887 \mathrm{n}$ & $\ldots$ & 0.1 & 0.0 & -0.2 & -0.8 \\
\hline Hung & $\ldots$ & 0.910 & 0.909 & 0.924 & 0.903 & $0.865 \mathrm{~m}$ & $\ldots$ & 0.0 & 0.2 & -0.5 & -0.9 \\
\hline Rom & $\ldots$ & $\ldots$ & $\ldots$ & 0.919 & 0.885 & $0.865 \mathrm{~m}$ & $\ldots$ & $\ldots$ & $\ldots$ & -0.7 & -0.4 \\
\hline United & 0.900 & 0.901 & 0.844 & 0.846 & & $0.846 \mathrm{~d}$ & 0.0 & -0.7 & 0.0 & & \\
\hline Second b & & & & & & & & & & & \\
\hline & & $\cdots$ & 0.706 & 0.679 & 0.694 & $0.698 \mathrm{j}$ & $\ldots$ & $\ldots$ & -0.4 & 0.4 & 0.6 \\
\hline Eng & 0.685 & 0.760 & 0.733 & 0.691 & $\ldots$ & $0.671 \mathrm{~h}$ & 1.0 & -0.4 & -0.6 & $\ldots$ & $\ldots$ \\
\hline Neth & 0.753 & 0.782 & 0.702 & 0.669 & 0.647 & $0.647 \mathrm{i}$ & 0.4 & -1.1 & -0.5 & -0.7 & $\ldots$ \\
\hline Greec & & 0.777 & 0.765 & 0.735 & 0.671 & $0.668 \mathrm{j}$ & $\ldots$ & -0.2 & -0.4 & -1.8 & -0.5 \\
\hline Italy & & 0.694 & 0.652 & & 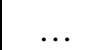 & $0.613 \mathrm{c}$ & $\ldots$ & -0.6 & $\ldots$ & $\ldots$ & $\ldots$ \\
\hline Czech & 0.714 & 0.744 & 0.799 & 0.783 & 0.742 & 0.7071 & 0.4 & 0.7 & -0.2 & -1.1 & -1.6 \\
\hline Hun & $\ldots$ & 0.646 & 0.719 & 0.725 & 0.691 & 0.6501 & $\ldots$ & 1.1 & 0.1 & -1.0 & -2.0 \\
\hline Rom & $\ldots$ & $\ldots$ & 0.723 & 0.674 & 0.576 & 0.4911 & $\ldots$ & $\ldots$ & -0.7 & -3.1 & -5.3 \\
\hline United & 0.802 & 0.783 & 0.665 & & $\ldots$ & $0.659 \mathrm{c}$ & -0.2 & -1.6 & & $\ldots$ & ... \\
\hline Third b & & & & & & & & & & & \\
\hline & & $\ldots$ & 0.230 & 0.243 & $\ldots$ & $0.253 \mathrm{~h}$ & $\ldots$ & $\ldots$ & 0.6 & $\ldots$ & $\ldots$ \\
\hline Eng & 0.382 & 0.394 & 0.299 & 0.297 & $\ldots$ & $0.287 \mathrm{f}$ & 0.3 & -2.8 & -0.1 & $\ldots$ & $\ldots$ \\
\hline Neth & 0.490 & 0.358 & 0.227 & 0.251 & $\ldots$ & $0.229 \mathrm{~h}$ & -3.2 & -4.5 & 1.0 & $\ldots$ & $\ldots$ \\
\hline Greec & & 0.284 & 0.254 & 0.213 & $\ldots$ & $0.190 \mathrm{~h}$ & $\ldots$ & -1.1 & -1.7 & $\ldots$ & $\ldots$ \\
\hline Ita & 0.363 & 0.322 & 0.232 & $\ldots$ & $\cdots$ & $0.201 \mathrm{a}$ & -1.2 & -3.3 & $\ldots$ & $\ldots$ & $\ldots$ \\
\hline Czec & 0.316 & 0.267 & 0.270 & 0.229 & 0.194 & $0.194 \mathrm{i}$ & -1.7 & 0.1 & -1.6 & -3.3 & $\ldots$ \\
\hline Huns & $\ldots$ & 0.205 & 0.210 & 0.237 & 0.242 & $0.242 \mathrm{i}$ & $\ldots$ & 0.2 & 1.2 & 0.4 & $\ldots$ \\
\hline Rom & & $\ldots$ & 0.361 & 0.285 & 0.218 & $0.201 \mathrm{j}$ & $\ldots$ & $\ldots$ & -2.4 & -5.4 & -8.1 \\
\hline United States & 0.584 & 0.508 & 0.311 & $\ldots$ & $\ldots$ & $0.308 \mathrm{~b}$ & -1.4 & -4.9 & $\ldots$ & $\ldots$ & $\ldots$ \\
\hline Four & & & & & & & & & & & \\
\hline & & & 0.071 & 0.085 & $\ldots$ & $0.089 \mathrm{f}$ & $\ldots$ & ... & 1.8 & ... & 2.2 \\
\hline Engl & 0.405 & 0.301 & 0.163 & 0.166 & $\ldots$ & $0.166 \mathrm{~d}$ & -2.9 & -6.1 & 0.2 & $\ldots$ & $\ldots$ \\
\hline Netherlands & 0.576 & 0.193 & 0.106 & 0.106 & $\ldots$ & $0.099 \mathrm{e}$ & -10.9 & -6.0 & 0.0 & $\ldots$ & -3.5 \\
\hline Greec & $\cdots$ & 0.142 & 0.097 & 0.079 & $\ldots$ & $0.073 \mathrm{f}$ & $\ldots$ & -3.8 & -2.0 & $\ldots$ & -4.5 \\
\hline Italy & 0.419 & 0.241 & 0.106 & $\ldots$ & $\ldots$ & $\ldots$ & -5.5 & -8.2 & $\ldots$ & $\ldots$ & $\ldots$ \\
\hline Czecl & 0.217 & 0.130 & 0.093 & 0.081 & $\ldots$ & $0.071 \mathrm{~g}$ & -5.2 & -3.3 & -1.4 & $\ldots$ & -4.5 \\
\hline Hungary & 0.252 & 0.160 & 0.114 & 0.131 & $\ldots$ & $0.139 \mathrm{~g}$ & -4.5 & -3.4 & 1.4 & $\ldots$ & 1.9 \\
\hline Romania & $\ldots$ & $\ldots$ & 0.381 & 0.300 & $\ldots$ & $0.273 \mathrm{f}$ & $\ldots$ & $\ldots$ & -2.4 & $\ldots$ & -4.8 \\
\hline United States & & 0.538 & 0.198 & 0.193 & $\ldots$ & $0.193 \mathrm{~d}$ & $\ldots$ & -10.0 & -0.2 & $\ldots$ & $\ldots$ \\
\hline
\end{tabular}

Notes : $a=1956, b=1957, c=1958, d=1960, e=1961, f=1962, g=1963, h=1964, i=1965, j=1966, k=1967, l=1968$, $\mathrm{m}=1970, \mathrm{n}=1971$. 
Table 2 - First, second, third, fourth and higher birth order cohort mean age, selected low fertility countries, birth cohorts 1930, 1940, 1950, 1960 and the latest available

\begin{tabular}{|c|c|c|c|c|c|c|c|c|c|c|c|}
\hline \multirow{2}{*}{ Country } & \multicolumn{6}{|c|}{ Mean age at first birth of cohort born in } & \multicolumn{5}{|c|}{$\begin{array}{l}\text { Annual change between birth } \\
\text { cohorts (percent) }\end{array}$} \\
\hline & 1930 & 1940 & 1950 & 1960 & 1965 & $\begin{array}{c}\text { Latest } \\
\text { available }\end{array}$ & $\begin{array}{l}1930- \\
1940\end{array}$ & $\begin{array}{l}1940- \\
1950\end{array}$ & $\begin{array}{l}1950- \\
1960\end{array}$ & $\begin{array}{l}1960- \\
1965\end{array}$ & $\begin{array}{l}\text { 1965- } \\
\text { latest }\end{array}$ \\
\hline First births & & & & & & & & & & & \\
\hline Den & & $\ldots$ & 23.91 & 26.20 & 27.20 & $27.41 \mathrm{k}$ & $\ldots$ & $\ldots$ & 0.9 & 0.8 & 0.3 \\
\hline England \& Wales & 24.94 & 23.89 & 24.22 & 25.83 & 26.34 & 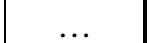 & -0.4 & 0.1 & 0.6 & 0.4 & $\ldots$ \\
\hline Netherlands & 26.03 & 24.98 & 25.07 & 27.54 & 28.40 & $28.71 \mathrm{j}$ & -0.4 & 0.0 & 0.9 & 0.6 & 0.5 \\
\hline Greece & $\ldots$ & $\ldots$ & 24.51 & 24.30 & 25.36 & $25.93 \mathrm{j}$ & $\ldots$ & $\ldots$ & -0.1 & 0.9 & 1.1 \\
\hline Italy & $\ldots$ & 25.35 & 24.86 & 26.01 & $\ldots$ & $26.30 \mathrm{e}$ & $\ldots$ & -0.2 & 0.5 & $\ldots$ & 1.1 \\
\hline Czech Republic & $\ldots$ & 22.48 & 22.57 & 22.35 & 22.54 & $23.28 n$ & $\ldots$ & 0.0 & -0.1 & 0.2 & 0.5 \\
\hline Hungary & $\ldots$ & 22.77 & 22.68 & 22.51 & 23.06 & $23.92 \mathrm{~m}$ & 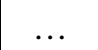 & 0.0 & -0.1 & 0.5 & 0.7 \\
\hline Romania & 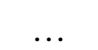 & $\ldots$ & $\ldots$ & 22.27 & 22.50 & $23.30 n$ & $\ldots$ & $\ldots$ & $\ldots$ & 0.2 & 0.6 \\
\hline United States & 22.51 & 22.00 & 23.45 & 24.53 & $\ldots$ & $24.61 \mathrm{e}$ & -0.2 & 0.6 & 0.5 & $\ldots$ & $\ldots$ \\
\hline Second births & & & & & & & & & & & \\
\hline Denr & $\ldots$ & $\ldots$ & 27.15 & 29.45 & 30.00 & $30.08 \mathrm{i}$ & $\ldots$ & $\ldots$ & 0.8 & 0.4 & 0.1 \\
\hline England \& Wales & 27.84 & 26.33 & 26.91 & 28.33 & & $28.76 \mathrm{~g}$ & -0.6 & 0.2 & 0.5 & $\ldots$ & $\ldots$ \\
\hline Netherlands & 28.63 & 27.43 & 27.64 & 29.81 & 30.72 & $30.90 \mathrm{i}$ & -0.4 & 0.1 & 0.8 & 0.6 & 0.6 \\
\hline Greece & $\ldots$ & 28.33 & 26.84 & 26.70 & 27.89 & $28.18 \mathrm{i}$ & $\ldots$ & $\ldots$ & 0.0 & 0.9 & 1.0 \\
\hline Italy & 29.05 & 28.24 & 27.88 & $\ldots$ & $\cdots$ & $29.06 \mathrm{c}$ & $\ldots$ & -0.1 & $\ldots$ & $\ldots$ & $\ldots$ \\
\hline Czech Republic & 25.93 & 25.94 & 25.63 & 25.30 & 25.83 & 26.461 & $\ldots$ & -0.1 & -0.1 & 0.4 & 0.6 \\
\hline Hungary & $\ldots$ & 26.65 & 25.97 & 25.83 & 26.27 & $26.65 \mathrm{k}$ & $\ldots$ & -0.3 & -0.1 & 0.3 & 0.5 \\
\hline Romania & & $\ldots$ & 25.10 & 24.64 & 24.58 & $25.32 \mathrm{k}$ & & $\ldots$ & $\ldots$ & 0.0 & 1.0 \\
\hline United States & 24.99 & 24.24 & 26.35 & 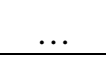 & $\ldots$ & $27.36 \mathrm{c}$ & -0.3 & 0.8 & $\ldots$ & $\ldots$ & 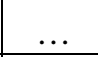 \\
\hline Third births & & & & & & & & & & & \\
\hline Denn & ... & $\ldots$ & 30.21 & 32.29 & 32.43 & $32.43 \mathrm{~h}$ & $\ldots$ & $\ldots$ & 0.7 & 0.1 & $\ldots$ \\
\hline England \& Wales & 30.09 & 28.03 & 29.09 & 29.90 & & $30.04 \mathrm{f}$ & -0.7 & 0.4 & 0.3 & $\ldots$ & 0.2 \\
\hline Netherlands & 30.80 & 29.08 & 30.47 & 31.58 & 32.34 & $32.34 \mathrm{~h}$ & -0.6 & 0.5 & 0.4 & 0.5 & $\ldots$ \\
\hline Greece & $\ldots$ & 30.41 & 28.75 & 28.93 & 29.84 & $29.84 h$ & $\ldots$ & $\ldots$ & 0.1 & 0.6 & $\ldots$ \\
\hline Italy & 31.18 & 30.14 & 30.10 & $\ldots$ & $\ldots$ & $31.05 \mathrm{a}$ & $\ldots$ & 0.0 & $\ldots$ & $\ldots$ & $\ldots$ \\
\hline Czech Rep & 27.83 & 28.49 & 28.46 & 28.62 & 29.45 & $29.45 \mathrm{~h}$ & 0.2 & 0.0 & 0.1 & 0.6 & $\ldots$ \\
\hline Hungary & $\ldots$ & 28.62 & 28.45 & 29.09 & 29.26 & $29.26 \mathrm{~h}$ & $\ldots$ & -0.1 & 0.2 & 0.1 & $\ldots$ \\
\hline Romania & $\ldots$ & $\ldots$ & 26.92 & 26.08 & 25.70 & $25.75 \mathrm{i}$ & $\ldots$ & $\ldots$ & $\ldots$ & -0.3 & 0.2 \\
\hline United States & 27.29 & 25.98 & 28.36 & $\ldots$ & $\ldots$ & $29.21 \mathrm{~b}$ & -0.5 & 0.9 & $\ldots$ & $\ldots$ & $\ldots$ \\
\hline Fourth and higher & & & & & & & & & & & \\
\hline Denmark & . & $\ldots$ & 32.92 & 34.46 & ... & $34.44 \mathrm{f}$ & $\ldots$ & $\ldots$ & 0.5 & $\ldots$ & 0.0 \\
\hline England \& Wales & 32.51 & 30.08 & 31.63 & 31.87 & $\ldots$ & $31.87 \mathrm{~d}$ & -0.8 & 0.5 & 0.1 & $\ldots$ & $\ldots$ \\
\hline Netherlands & 33.22 & 31.39 & 33.47 & 33.46 & $\ldots$ & $33.78 \mathrm{~g}$ & -0.6 & 0.6 & 0.0 & $\ldots$ & 0.3 \\
\hline Greece & $\ldots$ & 32.28 & 30.95 & 31.04 & $\ldots$ & $31.20 \mathrm{~g}$ & $\ldots$ & -0.4 & 0.0 & $\ldots$ & 0.2 \\
\hline Italy & 33.77 & 31.79 & 31.34 & $\ldots$ & $\ldots$ & $\ldots$ & -0.6 & -0.1 & $\ldots$ & $\ldots$ & $\ldots$ \\
\hline Czech Rer & 30.29 & 30.81 & 30.70 & 31.47 & $\ldots$ & $32.00 \mathrm{~g}$ & 0.2 & 0.0 & 0.2 & $\ldots$ & 0.6 \\
\hline Hungary & 30.68 & 30.71 & 30.70 & 31.68 & $\ldots$ & $31.67 \mathrm{~g}$ & 0.0 & 0.0 & 0.3 & $\ldots$ & 0.0 \\
\hline Romania & $\ldots$ & $\ldots$ & 30.61 & 29.13 & $\ldots$ & $28.98 \mathrm{~g}$ & $\ldots$ & $\ldots$ & -0.5 & $\ldots$ & -0.2 \\
\hline United States & $\ldots$ & 28.44 & 30.81 & 31.57 & $\ldots$ & $31.57 \mathrm{~d}$ & $\ldots$ & 0.8 & 0.2 & $\ldots$ & 0.0 \\
\hline
\end{tabular}

Notes : $a=1957, b=1958, c=1959, d=1960, e=1961, f=1962, g=1963, h=1965, i=1966, j=1967, k=1968, l=1969, m=1970$, $\mathrm{n}=1971$. 
Table 3 - The proportion of first, second, third, fourth and higher birth order total cohort fertility rate (TCFR) completed by 27th birthday, selected low fertility countries, birth cohorts 1930, 1940, 1950, 1960, 1965 and 1970.

\begin{tabular}{|c|c|c|c|c|c|c|c|c|c|c|c|}
\hline \multirow{2}{*}{ Country } & \multicolumn{6}{|c|}{$\begin{array}{c}\text { Proportion of TCFR completed up to } 27^{\text {th }} \\
\text { birthday of cohort born in }\end{array}$} & \multicolumn{5}{|c|}{$\begin{array}{c}\text { Annual change between } \\
\text { birth cohorts (percent) }\end{array}$} \\
\hline & 1930 & 1940 & 1950 & 1960 & 1965 & 1970 & $\begin{array}{l}1930- \\
1940\end{array}$ & $\begin{array}{l}1940- \\
1950\end{array}$ & $\begin{array}{l}1950- \\
1960\end{array}$ & $\begin{array}{l}1960- \\
1965 \\
\end{array}$ & $\begin{array}{l}1965- \\
1970\end{array}$ \\
\hline First birth & & & & & & & & & & & \\
\hline Denmark & $\ldots$ & $\ldots$ & $\ldots$ & 60.0 & 51.6 & $\ldots$ & $\ldots$ & $\ldots$ & $\ldots$ & -3.0 & $\ldots$ \\
\hline England \& Wales & 72.0 & 81.0 & 73.1 & 61.3 & $\ldots$ & $\ldots$ & 1.2 & -1.0 & -1.8 & $\ldots$ & $\ldots$ \\
\hline Netherlands & $\ldots$ & 74.8 & 71.2 & 48.0 & 39.7 & $\ldots$ & $\ldots$ & -0.5 & -4.0 & -3.8 & $\ldots$ \\
\hline Greece & $\ldots$ & $\ldots$ & 74.2 & 73.9 & 64.4 & $\ldots$ & $\ldots$ & $\ldots$ & 0.0 & -2.8 & $\ldots$ \\
\hline Italy & $\ldots$ & 70.6 & 73.7 & 60.5 & $\ldots$ & $\ldots$ & $\ldots$ & 0.4 & -2.0 & $\ldots$ & $\ldots$ \\
\hline Czech Republic & $\ldots$ & 90.3 & 90.1 & 89.9 & 89.3 & 82.8 & $\ldots$ & 0.0 & 0.0 & -0.1 & -1.5 \\
\hline Hungary & $\ldots$ & 86.3 & 87.7 & 87.0 & 84.3 & 76.4 & $\ldots$ & 0.2 & -0.1 & -0.6 & -2.0 \\
\hline Romania & $\ldots$ & $\ldots$ & $\ldots$ & 89.5 & 87.0 & 82.2 & $\ldots$ & $\ldots$ & $\ldots$ & -0.6 & -1.1 \\
\hline United States & 86.7 & 88.0 & 76.8 & 68.2 & $\ldots$ & $\ldots$ & 0.2 & -1.4 & -1.2 & $\ldots$ & $\ldots$ \\
\hline Second birth & & & & & & & & & & & \\
\hline Denmark & $\ldots$ & $\ldots$ & 52.7 & 31.4 & 25.7 & $\ldots$ & $\ldots$ & $\ldots$ & -5.2 & -4.0 & $\ldots$ \\
\hline England \& Wales & 46.5 & 61.2 & 53.8 & 43.4 & $\ldots$ & $\ldots$ & 2.7 & -1.3 & -2.1 & $\ldots$ & $\ldots$ \\
\hline Netherlands & 35.9 & 47.7 & 47.1 & 28.3 & 21.5 & $\ldots$ & 2.8 & -0.1 & -5.1 & -5.5 & $\ldots$ \\
\hline Greece & $\ldots$ & 41.3 & 56.2 & 58.1 & 47.5 & $\ldots$ & $\ldots$ & 3.1 & 0.3 & -4.0 & $\ldots$ \\
\hline Italy & $\ldots$ & 41.7 & 46.6 & $\ldots$ & $\ldots$ & $\ldots$ & $\ldots$ & 1.1 & $\ldots$ & $\ldots$ & $\ldots$ \\
\hline Czech Republic & $\ldots$ & 66.0 & 70.1 & 71.3 & 67.9 & $\ldots$ & $\ldots$ & 0.6 & 0.2 & -1.0 & $\ldots$ \\
\hline Hungary & $\ldots$ & 55.0 & 65.9 & 63.4 & 62.1 & $\ldots$ & $\ldots$ & 1.8 & -0.4 & -0.4 & $\ldots$ \\
\hline Romania & $\ldots$ & $\ldots$ & 70.9 & 74.9 & 76.4 & $\ldots$ & $\ldots$ & $\ldots$ & 0.5 & 0.4 & $\ldots$ \\
\hline United States & 71.8 & 76.4 & 58.6 & & $\ldots$ & $\ldots$ & 0.6 & -2.6 & & $\ldots$ & $\ldots$ \\
\hline Third birth & & & & & & & & & & & \\
\hline Denmark & $\ldots$ & $\ldots$ & 28.0 & 11.5 & $\ldots$ & $\ldots$ & $\ldots$ & $\ldots$ & -8.9 & $\ldots$ & $\ldots$ \\
\hline England \& Wales & 27.8 & 44.7 & 36.9 & 31.3 & $\ldots$ & $\ldots$ & 4.7 & -1.9 & -1.6 & $\ldots$ & $\ldots$ \\
\hline Netherlands & 18.6 & 29.2 & 19.6 & 14.7 & $\ldots$ & $\ldots$ & 4.5 & -4.0 & -2.9 & $\ldots$ & $\ldots$ \\
\hline Greece & $\ldots$ & 24.9 & 38.7 & 41.6 & $\ldots$ & $\ldots$ & $\ldots$ & 4.4 & 0.7 & $\ldots$ & $\ldots$ \\
\hline Italy & $\ldots$ & 26.4 & 30.7 & $\ldots$ & $\ldots$ & $\ldots$ & $\ldots$ & 1.5 & $\ldots$ & $\ldots$ & $\ldots$ \\
\hline Czech Republic & 48.8 & 44.4 & 40.9 & 40.9 & 37.3 & $\ldots$ & -0.9 & -0.8 & 0.0 & -1.9 & $\ldots$ \\
\hline Hungary & $\ldots$ & 40.7 & 44.8 & 35.5 & 35.9 & $\ldots$ & $\ldots$ & 1.0 & -2.3 & 0.2 & $\ldots$ \\
\hline Romania & $\ldots$ & $\ldots$ & 59.4 & 63.6 & 71.5 & $\ldots$ & $\ldots$ & $\ldots$ & 0.7 & 2.3 & $\ldots$ \\
\hline United States & 51.1 & 63.1 & 42.3 & $\ldots$ & $\ldots$ & $\ldots$ & 2.1 & -4.0 & $\ldots$ & $\ldots$ & $\ldots$ \\
\hline Fourth birth & & & & & & & & & & & \\
\hline Denmark & $\ldots$ & $\ldots$ & 15.4 & 4.9 & $\ldots$ & $\ldots$ & $\ldots$ & $\ldots$ & -11.4 & $\ldots$ & $\ldots$ \\
\hline England \& Wales & 12.1 & 29.1 & 21.9 & 19.0 & $\ldots$ & $\ldots$ & 8.8 & -2.9 & -1.4 & ... & $\ldots$ \\
\hline Netherlands & 7.2 & 17.9 & 7.6 & 7.6 & $\ldots$ & $\ldots$ & 9.0 & -8.6 & 0.0 & $\ldots$ & $\ldots$ \\
\hline Greece & $\ldots$ & 15.3 & 23.7 & 26.0 & $\ldots$ & $\ldots$ & $\ldots$ & 4.4 & 0.9 & $\ldots$ & $\ldots$ \\
\hline Italy & $\ldots$ & 16.1 & 24.3 & $\ldots$ & $\ldots$ & $\ldots$ & $\ldots$ & 4.1 & $\ldots$ & $\ldots$ & $\ldots$ \\
\hline Czech Republic & 30.8 & 25.9 & 25.5 & 22.0 & $\ldots$ & $\ldots$ & -1.7 & -0.2 & -1.5 & $\ldots$ & $\ldots$ \\
\hline Hungary & $\ldots$ & 26.1 & 30.4 & 21.0 & $\ldots$ & $\ldots$ & $\ldots$ & 1.5 & -3.7 & $\ldots$ & $\ldots$ \\
\hline Romania & $\ldots$ & $\ldots$ & 29.3 & 37.7 & $\ldots$ & $\ldots$ & $\ldots$ & $\ldots$ & 2.5 & $\ldots$ & $\ldots$ \\
\hline United States & $\ldots$ & 43.6 & 26.3 & $\ldots$ & $\ldots$ & $\ldots$ & $\ldots$ & -5.0 & $\ldots$ & $\ldots$ & $\ldots$ \\
\hline
\end{tabular}


Table 4 - Cumulated cohort fertility rates after 27th birthday, first, second, third, fourth and higher birth order, selected low fertility countries, birth cohorts 1930, 1940, 1950, 1960, 1965 and 1970.

\begin{tabular}{|c|c|c|c|c|c|c|c|c|c|c|c|}
\hline \multirow[t]{2}{*}{ Country } & \multicolumn{6}{|c|}{ Cumulated fertility after $27^{\text {th }}$ Birthday } & \multicolumn{5}{|c|}{$\begin{array}{c}\text { Decennial change between cohorts } \\
\text { (percent) }\end{array}$} \\
\hline & 1930 & 1940 & 1950 & 1960 & 1965 & 1970 & \begin{tabular}{|c|}
$1930-$ \\
1940
\end{tabular} & $\begin{array}{l}1940- \\
1950\end{array}$ & $\begin{array}{l}1950- \\
1960\end{array}$ & $\begin{array}{l}1960- \\
1965\end{array}$ & $\begin{array}{l}1965- \\
1970\end{array}$ \\
\hline First births & & & & & & & & & & & \\
\hline Denn & r & $\ldots$ & $\ldots$ & 0.360 & 0.422 & $\ldots$ & $\ldots$ & $\ldots$ & ... & 17.4 & $\ldots$ \\
\hline England \& Wales & 0.243 & 0.169 & 0.231 & 0.314 & & $\ldots$ & -30.4 & 36.6 & 35.7 & $\ldots$ & $\ldots$ \\
\hline Netherlands & $\ldots$ & 0.223 & 0.246 & 0.429 & 0.493 & $\ldots$ & $\ldots$ & 10.0 & 74.5 & 14.9 & $\ldots$ \\
\hline Greece & $\ldots$ & & 0.233 & 0.233 & 0.297 & $\ldots$ & $\ldots$ & $\ldots$ & -0.2 & 27.5 & $\ldots$ \\
\hline Italy & $\cdots$ & 0.251 & 0.229 & 0.335 & & $\cdots$ & $\begin{array}{l}\cdots \\
\cdots\end{array}$ & -8.8 & 46.5 & $\ldots$ & $\begin{array}{l}\cdots \\
\ldots\end{array}$ \\
\hline Czech Republic & $\ldots$ & 0.090 & 0.092 & 0.095 & 0.099 & 0.156 & $\ldots$ & 3.1 & 2.2 & 4.9 & 56.9 \\
\hline Hungary & $\begin{array}{l}\cdots \\
\cdots\end{array}$ & 0.124 & 0.112 & 0.120 & 0.142 & 0.204 & $\begin{array}{l}\cdots \\
\ldots\end{array}$ & -10.2 & 7.5 & 18.5 & 43.6 \\
\hline Romania & & & $\ldots$ & 0.096 & 0.115 & 0.154 & $\ldots$ & $\cdots$ & $\ldots$ & 19.6 & 33.4 \\
\hline United States & 0.120 & 0.108 & 0.196 & 0.269 & $\ldots$ & $\ldots$ & -10.0 & 81.3 & 37.8 & $\ldots$ & $\ldots$ \\
\hline Second births & & & & & & & & & & & \\
\hline Den & & & 0.334 & 0.466 & 0.516 & $\ldots$ & $\ldots$ & $\ldots$ & 39.5 & 10.8 & $\ldots$ \\
\hline $1 \&$ Wales & 0.367 & 0.295 & 0.339 & 0.391 & $\ldots$ & $\ldots$ & -19.6 & 15.0 & 15.4 & $\ldots$ & $\ldots$ \\
\hline Netherlands & 0.482 & 0.409 & 0.371 & 0.480 & 0.508 & $\ldots$ & -15.1 & -9.3 & 29.3 & 5.8 & $\ldots$ \\
\hline Greece & $\ldots$ & 0.456 & 0.335 & 0.308 & 0.352 & $\ldots$ & $\ldots$ & -26.6 & -8.1 & 14.5 & $\ldots$ \\
\hline Italy & $\ldots$ & 0.405 & 0.348 & $\ldots$ & $\ldots$ & $\ldots$ & $\ldots$ & -14.0 & $\ldots$ & $\ldots$ & $\ldots$ \\
\hline Czech Republic & $\ldots$ & 0.253 & 0.239 & 0.225 & 0.238 & $\ldots$ & $\ldots$ & -5.6 & -5.8 & 5.9 & $\ldots$ \\
\hline Hungary & $\ldots$ & 0.291 & 0.245 & 0.265 & 0.262 & $\ldots$ & $\ldots$ & -15.7 & 8.2 & -1.1 & $\ldots$ \\
\hline Romania & $\ldots$ & $\ldots$ & $\ldots$ & 0.169 & 0.136 &.. & $\ldots$ & $\ldots$ & $\ldots$ & -19.9 & $\ldots$ \\
\hline United States & 0.226 & 0.185 & 0.275 & $\ldots$ & $\ldots$ & $\ldots$ & -18.0 & 48.8 & $\ldots$ & $\ldots$ & $\ldots$ \\
\hline Third b & & & & & & & & & & & \\
\hline Denn & & $\cdots$ & 0.166 & 0.216 & $\ldots$ & $\ldots$ & $\ldots$ & $\ldots$ & 30.1 & $\ldots$ & $\ldots$ \\
\hline Engl & 0.276 & 0.218 & 0.189 & 0.204 & $\ldots$ & $\ldots$ & -20.9 & -13.4 & 8.2 & $\ldots$ & $\ldots$ \\
\hline Nethe & 0.399 & 0.253 & 0.183 & 0.215 & $\ldots$ & $\ldots$ & -36.5 & -27.8 & 17.3 & $\ldots$ & $\ldots$ \\
\hline Greece & $\ldots$ & 0.213 & 0.155 & 0.124 & $\ldots$ & $\ldots$ & $\ldots$ & -27.0 & -19.9 & $\ldots$ & $\ldots$ \\
\hline Italy & $\ldots$ & 0.237 & 0.161 & $\ldots$ & $\ldots$ & $\ldots$ & $\ldots$ & -32.4 & $\ldots$ & $\ldots$ & $\ldots$ \\
\hline Czech & 0.162 & 0.149 & 0.160 & 0.135 & 0.122 & $\ldots$ & -0.154 & 7.4 & -15.1 & -10.3 & $\ldots$ \\
\hline Hung & $\ldots$ & 0.121 & 0.116 & 0.153 & 0.155 & $\ldots$ & $\ldots$ & -4.7 & 32.4 & 1.5 & $\ldots$ \\
\hline Rome & $\ldots$ & $\ldots$ & 0.147 & 0.104 & 0.062 &.. & $\ldots$ & $\ldots$ & -29.3 & -40.1 & $\ldots$ \\
\hline United States & 0.286 & 0.187 & 0.179 & 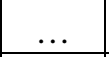 & $\ldots$ & $\ldots$ & -34.4 & -4.3 & $\ldots$ & $\ldots$ & $\ldots$ \\
\hline Fourth and higher & & & & & & & & & & & \\
\hline Denmark & $\ldots$ & $\ldots$ & 0.060 & 0.081 & $\ldots$ & $\ldots$ & $\ldots$ & $\ldots$ & 34.9 & $\ldots$ & $\ldots$ \\
\hline Engla & 0.356 & 0.214 & 0.128 & 0.135 & $\ldots$ & $\ldots$ & -39.9 & -40.3 & 5.6 & $\ldots$ & $\ldots$ \\
\hline Netherlands & 0.535 & 0.159 & 0.098 & 0.098 & $\ldots$ & $\ldots$ & -70.3 & -38.3 & 0.2 & $\ldots$ & $\ldots$ \\
\hline Greece & $\ldots$ & 0.120 & 0.074 & 0.059 & $\ldots$ & $\ldots$ & $\ldots$ & -38.5 & -20.6 & $\ldots$ & $\ldots$ \\
\hline Italy & $\cdots$ & 0.202 & 0.080 & $\cdots$ & $\ldots$ & $\ldots$ & $\ldots$ & -60.4 & $\ldots$ & $\ldots$ & $\ldots$ \\
\hline Czech $\mathrm{Re}_{1}$ & 0.151 & 0.096 & 0.070 & 0.063 & $\ldots$ & $\ldots$ & -0.067 & -27.5 & -9.3 & $\ldots$ & $\ldots$ \\
\hline Hungary & $\ldots$ & 0.118 & 0.079 & 0.103 & $\ldots$ & $\ldots$ & $\ldots$ & -33.2 & 30.7 & $\ldots$ & $\ldots$ \\
\hline Roma & $\cdots$ & $\ldots$ & 0.269 & 0.187 & .. & .. & $\ldots$ & $\ldots$ & -30.6 &.. & $\ldots$ \\
\hline United States & $\ldots$ & 0.304 & 0.146 & 0.152 & $\ldots$ & $\ldots$ & $\ldots$ & -52.0 & 4.3 & $\ldots$ & $\ldots$ \\
\hline
\end{tabular}


Table 5 - First, second, third, fourth and higher birth order cumulated cohort fertility rates (CCFRs) up to $27^{\text {th }}$ birthday, selected low fertility countries, birth cohorts 1930, 1940, 1950, 1960, 1970 and 1975 (or latest available)

\begin{tabular}{|c|c|c|c|c|c|c|c|c|c|c|c|c|c|}
\hline \multirow[b]{2}{*}{ Country } & \multicolumn{7}{|c|}{ CCFR up to $27^{\text {th }}$ birthday } & \multicolumn{6}{|c|}{$\begin{array}{c}\text { Annual change between birth cohorts } \\
\text { (percent) }\end{array}$} \\
\hline & 1930 & 1940 & 1950 & 1960 & 1965 & \begin{tabular}{l|l}
1970 & 1 \\
& $\mathrm{a}$ \\
\end{tabular} & \begin{tabular}{|c|}
$\begin{array}{c}1975 \text { or } \\
\text { latest } \\
\text { available }\end{array}$ \\
\end{tabular} & $\begin{array}{c}1930- \\
1940\end{array}$ & $\begin{array}{l}1940- \\
1950 \\
\end{array}$ & $\begin{array}{l}1950- \\
1960 \\
\end{array}$ & $1960-$ & \begin{tabular}{c|c}
$1965-$ & 19 \\
1970 & $(c$ \\
av \\
\end{tabular} & $\begin{array}{l}970-1975 \\
\text { (or latest } \\
\text { available) } \\
\text { velal }\end{array}$ \\
\hline Fi & & & & & & & & & & & & & \\
\hline & . & $\ldots$ & $\ldots$ & 0.539 & \begin{tabular}{|l|l}
0.451 & 0
\end{tabular} & 0.421 & 0.350 & $\ldots$ & $\ldots$ & $\ldots$ & -3.6 & -1.4 & -3.7 \\
\hline England \& Wales & 0.627 & 0.723 & 0.630 & 0.497 & \begin{tabular}{|l|l|}
0.455 & 0
\end{tabular} & 0.433 & $0.392 \mathrm{c}$ & 1.4 & -1.4 & -2.4 & -1.8 & -1.0 & -2.5 \\
\hline Netherlands & $\ldots$ & 0.665 & 0.608 & 0.395 & \begin{tabular}{|l|l|l|l}
0.324 & 0
\end{tabular} & 0.268 & 0.268 & $\ldots$ & -0.9 & -4.3 & -4.0 & -3.8 & 0.1 \\
\hline Greece & $\ldots$ & $\ldots$ & 0.670 & 0.661 & \begin{tabular}{|l|l|}
0.537 & 0
\end{tabular} & 0.397 & 0.311 & $\ldots$ & $\ldots$ & -0.1 & -4.1 & -6.1 & -4.9 \\
\hline Italy & $\ldots$ & 0.604 & 0.641 & 0.514 & \begin{tabular}{|l|l}
0.391 & 0
\end{tabular} & 0.298 ( & $0.298 \mathrm{~b}$ & $\ldots$ & 0.6 & -2.2 & -5.5 & -5.5 & $\ldots$ \\
\hline Czec & $\ldots$ & 0.833 & 0.841 & 0.842 & $|0.830| 0$ & 0.748 & 0.536 & $\ldots$ & 0.1 & 0.0 & -0.3 & -2.1 & -6.6 \\
\hline Hungary & $\ldots$ & 0.785 & 0.797 & 0.804 & \begin{tabular}{|l|l|l|l|l}
0.761 & 0
\end{tabular} & 0.661 & 0.481 & $\ldots$ & 0.1 & 0.1 & -1.1 & -2.8 & -6.4 \\
\hline Roma & $\ldots$ & $\ldots$ & $\ldots$ & 0.822 & $0.770 \mid 0$ & 0.712 & 0.569 & $\ldots$ & $\ldots$ & $\ldots$ & -1.3 & -1.6 & -4.5 \\
\hline United States & 0.780 & 0.793 & 0.649 & 0.577 & 0.563 & 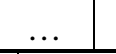 & $\ldots$ & 0.2 & -2.0 & -1.2 & -0.5 & .. & ... \\
\hline Second births & & & & & & & & & & & & & \\
\hline Denn & 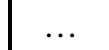 & $\ldots$ & 0.372 & 0.213 & \begin{tabular}{|l|l|}
3 & 0.179 \\
\end{tabular} & 0.160 & \begin{tabular}{l|l|}
0 & 0.140
\end{tabular} & $\ldots$ & $\ldots$ & -5.6 & -3.5 & -2.2 & -2.7 \\
\hline England \& & 0.318 & 0.465 & 0.394 & 0.300 & 0.257 & 0.233 & $\begin{array}{lll}3 & 0.214 c\end{array}$ & 3.8 & -1.6 & -2.7 & -3.1 & -1.9 & -2.2 \\
\hline Netherlands & 0.271 & 0.373 & 0.331 & 0.189 & \begin{tabular}{|l|l|}
9 & 0.139 \\
\end{tabular} & 0.106 & $6 \quad 0.101$ & 3.2 & -1.2 & -5.6 & -6.2 & -5.4 & -1.0 \\
\hline Greece & $\ldots$ & 0.321 & 0.430 & 0.427 & \begin{tabular}{|l|l|} 
& 0.319 \\
\end{tabular} & 0.203 & \begin{tabular}{|l|l|}
3 & 0.142
\end{tabular} & $\ldots$ & 2.9 & -0.1 & -5.9 & -9.0 & -7.2 \\
\hline Italy & $\ldots$ & 0.290 & 0.304 & 0.214 & \begin{tabular}{ll|}
4 & 0.143 \\
\end{tabular} & 0.097 & $7 \mid 0.097 \mathrm{~b}$ & $\ldots$ & 0.5 & -3.5 & -8.1 & -7.8 & . \\
\hline Czech Republic & $\ldots$ & 0.491 & 0.560 & 0.558 & \begin{tabular}{|l|l|}
3 & 0.504
\end{tabular} & 0.394 & $\begin{array}{ll}4 & 0.219\end{array}$ & $\ldots$ & 1.3 & 0.0 & -2.0 & -4.9 & -11.7 \\
\hline Hungary & $\cdots$ & 0.356 & 0.474 & 0.460 & 0.429 & 0.334 & $4 \mid 0.200$ & $\ldots$ & 2.9 & -0.3 & -1.4 & -5.0 & -10.2 \\
\hline Romania & $\ldots$ & $\ldots$ & 0.513 & 0.504 & \begin{tabular}{|l|l|}
4 & 0.440 \\
\end{tabular} & 0.297 & \begin{tabular}{|l|l|}
7 & 0.224 \\
\end{tabular} & $\ldots$ & $\ldots$ & -0.2 & -2.7 & -7.9 & -5.6 \\
\hline United State & 0.576 & 0.598 & 0.390 & 0.330 & 0.316 & .. & $0.312 \mathrm{a}$ & 0.4 & -4.3 & -1.7 & -0.8 & $\ldots$ & $\ldots$ \\
\hline Third & & & & & & & & & & & & & \\
\hline & & & 0.064 & 0.028 & \begin{tabular}{l|l}
8 & 0.027
\end{tabular} & 0.030 & \begin{tabular}{l|l|}
0 & 0.025
\end{tabular} & 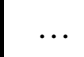 & $\cdots$ & -8.3 & -0.7 & 2.1 & -3.3 \\
\hline Engla & 0.106 & 0.176 & 0.110 & 0.093 & $\begin{array}{ll}3 & 0.086\end{array}$ & 0.076 & \begin{tabular}{l|l|l|}
6 & $0.067 \mathrm{c}$
\end{tabular} & 5.0 & -4.7 & -1.7 & -1.7 & -2.4 & -3.1 \\
\hline Netherlands & 0.091 & 0.104 & 0.045 & 0.037 & \begin{tabular}{l|l}
7 & 0.028
\end{tabular} & \begin{tabular}{|l|l}
3 & 0.021
\end{tabular} & $1 \mid$ & 1.3 & -8.5 & -1.9 & -5.8 & -5.9 & -1.6 \\
\hline Greece & $\ldots$ & 0.071 & 0.098 & 0.089 & $\begin{array}{ll}9 & 0.063\end{array}$ & 0.038 & \begin{tabular}{l|l|}
8 & 0.027
\end{tabular} & $\ldots$ & 3.3 & -1.0 & -7.0 & -10.1 & -6.7 \\
\hline Italy & $\cdots$ & 0.085 & 0.071 & 0.036 & $\begin{array}{ll}6 & 0.020\end{array}$ & 0.012 & $20.012 b$ & $\ldots$ & -1.8 & -6.9 & -11.1 & -9.8 & $\ldots$ \\
\hline Czech Re & 0.154 & 0.119 & 0.111 & 0.094 & \begin{tabular}{l|l}
4 & 0.072
\end{tabular} & 0.047 & \begin{tabular}{l|l|}
7 & 0.025
\end{tabular} & -2.6 & -0.7 & -1.7 & -5.2 & -8.5 & -13.1 \\
\hline Hungary & $\ldots$ & 0.083 & 0.094 & 0.084 & $\begin{array}{lll}4 & 0.087\end{array}$ & 0.079 & \begin{tabular}{l|l|}
9 & 0.055
\end{tabular} & $\ldots$ & 1.2 & -1.1 & 0.6 & -1.9 & -7.1 \\
\hline Romania & & $\cdots$ & 0.214 & 0.181 & 10.156 & \begin{tabular}{|l|l}
5 & 0.068
\end{tabular} & $8 \mid 0.055$ & $\ldots$ & $\ldots$ & -1.7 & -3.1 & -16.5 & \begin{tabular}{|l}
$\mid-4.3$ \\
\end{tabular} \\
\hline United States & 0.299 & 0.321 & 0.132 & 0.114 & \begin{tabular}{l|l}
4 & 0.121 \\
\end{tabular} & $\ldots$ & & 0.7 & -8.9 & -1.5 & 1.2 & $\ldots$ & $\ldots$ \\
\hline Four & & & & & & & & & & & & & \\
\hline Denn & $\ldots$ & $\ldots$ & 0.011 & 0.004 & $\begin{array}{ll}4 & 0.005\end{array}$ & 0.007 & \begin{tabular}{l|l}
7 & 0.006
\end{tabular} & $\ldots$ & ... & -9.6 & 3.2 & 7.0 & -3.0 \\
\hline England \& Wales & 0.049 & 0.088 & 0.036 & 0.032 & \begin{tabular}{l|l|}
2 & 0.027
\end{tabular} & 0.024 & $4 \mid 0.021 c$ & 5.9 & -9.0 & -1.2 & -3.0 & -2.6 & -3.1 \\
\hline Netherlands & 0.042 & 0.035 & 0.008 & 0.008 & \begin{tabular}{l|l}
8 & 0.006
\end{tabular} & 0.004 & $\begin{array}{lll}4 & 0.004\end{array}$ & -1.9 & -14.6 & 0.0 & -4.5 & -8.8 & -2.3 \\
\hline Greece & $\cdots$ & 0.022 & 0.023 & 0.021 & $\begin{array}{ll}1 & 0.016\end{array}$ & 50.011 & \begin{tabular}{l|l}
1 & 0.009
\end{tabular} & $\ldots$ & 0.6 & -1.1 & -5.4 & -6.6 & -3.6 \\
\hline Italy & 0.036 & 0.039 & 0.026 & 0.007 & $\begin{array}{ll}7 & 0.003\end{array}$ & 0.002 & $20.002 b$ & 0.8 & -4.1 & -13.1 & -14.7 & -9.9 & $\ldots$ \\
\hline Czech Republic & 0.067 & 0.034 & 0.024 & 0.018 & $\begin{array}{ll}8 & 0.014\end{array}$ & 0.011 & 10.007 & -6.9 & -3.4 & -2.9 & -5.5 & -4.6 & -8.4 \\
\hline Hungary & $\cdots$ & 0.042 & 0.035 & 0.027 & \begin{tabular}{l|l}
7 & 0.027
\end{tabular} & 0.028 & \begin{tabular}{l|l|}
8 & 0.022
\end{tabular} & 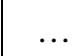 & -1.9 & -2.3 & 0.0 & 0.4 & -4.6 \\
\hline Romania & $\ldots$ & $\ldots$ & 0.112 & 0.113 & $\begin{array}{ll}3 & 0.089\end{array}$ & 0.032 & 20.027 & $\ldots$ & $\ldots$ & 0.2 & -4.8 & -20.4 & -3.4 \\
\hline United States & $\ldots$ & 0.235 & 0.052 & 0.041 & $\begin{array}{ll}1 & 0.051 \\
\end{array}$ & 0.054 & $\begin{array}{lll}4 & 0.055 \mathrm{c} \\
\end{array}$ & $\ldots$ & -15.1 & -2.3 & 4.1 & 1.1 & 0.7 \\
\hline
\end{tabular}

Notes : $a=1969, b=1970, c=1974$. 
Table 6 - Parity progression ratios (in percent), selected low fertility countries, birth cohorts 1930 - 1970

\begin{tabular}{|c|c|c|c|c|c|}
\hline \multirow{2}{*}{ Country } & \multirow{2}{*}{ Cohort } & \multicolumn{4}{|c|}{ Parity progression ratios } \\
\hline & & $0 \rightarrow 1$ & $1 \rightarrow 2$ & $2 \rightarrow 3$ & $3 \rightarrow 4$ \\
\hline \multirow[t]{5}{*}{ Denmark } & 1950 & 88.9 & 79.4 & 32.5 & 22.7 \\
\hline & 1955 & 87.5 & 78.2 & 32.7 & 23.5 \\
\hline & 1960 & 89.9 & 75.5 & 35.9 & 24.8 \\
\hline & 1965 & 87.3 & 79.5 & 36.1 & \\
\hline & 1968 & 87.8 & & & \\
\hline \multirow[t]{10}{*}{ England \& Wales } & 1920 & 82.8 & 73.0 & 53.0 & 48.4 \\
\hline & 1925 & 84.1 & 73.9 & 53.7 & 50.1 \\
\hline & 1930 & 87.0 & 78.7 & 55.8 & 51.2 \\
\hline & 1935 & 88.6 & 82.8 & 55.8 & 47.6 \\
\hline & 1940 & 89.3 & 85.1 & 51.9 & 43.9 \\
\hline & 1945 & 90.2 & 83.7 & 43.1 & 36.4 \\
\hline & 1950 & 86.1 & 85.2 & 40.8 & 35.2 \\
\hline & 1955 & 84.2 & 84.0 & 42.5 & 34.7 \\
\hline & 1960 & 81.1 & 85.2 & 43.0 & 34.4 \\
\hline & 1965 & 79.5 & & & \\
\hline \multirow[t]{9}{*}{ Netherlands } & 1930 & 85.7 & 87.8 & 65.1 & 55.8 \\
\hline & 1935 & 87.9 & 88.6 & 58.2 & 46.4 \\
\hline & 1940 & 88.8 & 88.1 & 45.7 & 33.3 \\
\hline & 1945 & 88.7 & 84.3 & 33.4 & 27.3 \\
\hline & 1950 & 85.4 & 82.2 & 32.4 & 27.4 \\
\hline & 1955 & 83.1 & 81.7 & 36.8 & 26.8 \\
\hline & 1960 & 82.4 & 81.2 & 37.6 & 20.8 \\
\hline & 1965 & 81.7 & 79.2 & 34.8 & \\
\hline & 1967 & 81.8 & & & \\
\hline \multirow[t]{7}{*}{ Italy } & 1935 & 84.8 & 81.3 & 52.4 & 46.6 \\
\hline & 1940 & 85.4 & 81.3 & 46.4 & 40.2 \\
\hline & 1945 & 88.3 & 78.9 & 41.0 & 35.2 \\
\hline & 1950 & 87.0 & 74.9 & 35.5 & 29.3 \\
\hline & 1955 & 87.3 & 72.4 & 32.7 & 25.2 \\
\hline & 1960 & 84.7 & & & \\
\hline & 1961 & 83.7 & & & \\
\hline \multirow[t]{9}{*}{ Czech republic } & 1935 & 93.5 & 79.0 & 38.8 & 32.0 \\
\hline & 1940 & 92.3 & 80.6 & 35.9 & 29.1 \\
\hline & 1945 & 92.0 & 82.5 & 33.5 & 25.0 \\
\hline & 1950 & 93.4 & 85.5 & 33.8 & 23.4 \\
\hline & 1955 & 93.8 & 84.8 & 31.4 & 23.0 \\
\hline & 1960 & 93.6 & 83.6 & 29.2 & 23.7 \\
\hline & 1965 & 92.8 & 80.0 & 26.1 & \\
\hline & 1970 & 90.6 & & & \\
\hline & 1971 & 89.1 & & & \\
\hline
\end{tabular}


Table 6 (continued) - Parity progression ratios (in percent), selected low fertility countries, birth cohorts 1930 1970

\begin{tabular}{|l|c|c|c|c|c|}
\hline \multirow{2}{*}{ Country } & \multirow{2}{*}{ Cohort } & \multicolumn{4}{|c|}{ Parity progression ratios } \\
\cline { 3 - 6 } & & $\mathbf{0} \boldsymbol{\rightarrow 1}$ & $\mathbf{1} \boldsymbol{\rightarrow 2}$ & $\mathbf{2} \rightarrow \mathbf{3}$ & $\mathbf{3} \boldsymbol{\rightarrow 4}$ \\
\hline Romania & 1950 & 93.7 & 77.1 & 49.9 & 55.9 \\
& 1955 & 91.0 & 76.1 & 44.8 & 53.0 \\
& 1960 & 91.8 & 73.4 & 42.3 & 50.2 \\
& 1965 & 88.5 & 65.0 & 37.8 & 45.7 \\
& 1970 & 86.8 & & & \\
& 1971 & 85.1 & & & \\
& & & & & \\
& 1905 & 78.9 & 70.6 & 62.2 & 33.8 \\
& 1910 & 78.9 & 72.5 & 60.3 & 60.6 \\
& 1915 & 83.1 & 76.6 & 61.1 & 54.0 \\
& 1920 & 88.1 & 80.8 & 64.2 & 52.5 \\
& 1925 & 89.8 & 85.2 & 68.6 & 54.7 \\
& 1930 & 90.0 & 89.1 & 72.9 & 58.1 \\
& 1935 & 91.7 & 89.2 & 72.5 & 63.6 \\
& 1940 & 90.1 & 86.9 & 64.9 & 65.3 \\
& 1945 & 87.1 & 82.2 & 52.5 & 58.7 \\
& 1950 & 84.4 & 78.8 & 46.8 & 44.0 \\
& 1955 & 84.0 & 78.2 & 46.6 & 36.8 \\
& 1960 & 84.7 & & & \\
& 1965 & 85.0 & & & \\
\hline
\end{tabular}


Table 7 - Parity distribution (in percent), selected low fertility countries, birth cohorts 1930 - 1960

\begin{tabular}{|c|c|c|c|c|c|c|c|}
\hline \multirow[b]{2}{*}{ Country } & \multirow[b]{2}{*}{ Cohort } & \multicolumn{5}{|c|}{ Parity } & \multirow{2}{*}{$\begin{array}{c}\text { Total } \\
\text { cohort } \\
\text { fertility } \\
\text { rate }\end{array}$} \\
\hline & & 0 & 1 & 2 & 3 & $\begin{array}{l}4 \text { and } \\
\text { more }\end{array}$ & \\
\hline \multirow[t]{2}{*}{ Denmark } & 1950 & 10.9 & 18.3 & 47.8 & 17.8 & 5.2 & 1.91 \\
\hline & 1955 & 12.5 & 19.1 & 46.0 & 17.1 & 5.3 & 1.84 \\
\hline \multirow[t]{6}{*}{ England \& Wales } & 1930 & 13.1 & 18.5 & 29.9 & 19.0 & 19.5 & 2.34 \\
\hline & 1935 & 11.2 & 15.2 & 32.9 & 21.3 & 19.4 & 2.41 \\
\hline & 1940 & 10.6 & 13.0 & 37.3 & 21.9 & 17.2 & 2.35 \\
\hline & 1945 & 10.4 & 13.7 & 43.2 & 21.1 & 11.6 & 2.16 \\
\hline & 1950 & 14.5 & 12.2 & 43.2 & 19.5 & 10.6 & 2.06 \\
\hline & 1955 & 16.9 & 12.1 & 40.0 & 20.5 & 10.5 & 2.02 \\
\hline \multirow[t]{7}{*}{ Netherlands } & 1930 & 14.1 & 10.6 & 26.3 & 21.6 & 27.4 & 2.67 \\
\hline & 1935 & 12.1 & 10.0 & 32.6 & 24.2 & 21.1 & 2.49 \\
\hline & 1940 & 11.2 & 10.6 & 42.5 & 23.8 & 11.9 & 2.22 \\
\hline & 1945 & 11.3 & 13.9 & 49.8 & 18.2 & 6.8 & 2.00 \\
\hline & 1950 & 14.6 & 15.2 & 47.5 & 16.5 & 6.2 & 1.89 \\
\hline & 1955 & 16.9 & 15.2 & 42.9 & 18.2 & 6.8 & 1.87 \\
\hline & 1960 & 17.7 & 15.5 & 41.7 & 19.5 & 5.6 & 1.85 \\
\hline \multirow[t]{5}{*}{ Italy } & 1935 & 15.3 & 15.8 & 32.8 & 19.3 & 16.8 & 2.28 \\
\hline & 1940 & 14.5 & 16.0 & 37.2 & 19.3 & 13.0 & 2.14 \\
\hline & 1945 & 11.7 & 18.6 & 41.1 & 18.5 & 10.1 & 2.07 \\
\hline & 1950 & 12.7 & 22.1 & 42.0 & 16.4 & 6.8 & 1.89 \\
\hline & 1955 & 12.4 & 24.3 & 42.5 & 15.5 & 5.3 & 1.80 \\
\hline \multirow[t]{6}{*}{ Czech Republic } & 1935 & 6.5 & 19.6 & 45.2 & 19.5 & 9.2 & 2.12 \\
\hline & 1940 & 7.6 & 18.0 & 47.7 & 18.9 & 7.8 & 2.07 \\
\hline & 1945 & 8.1 & 16.6 & 49.9 & 18.9 & 6.5 & 2.03 \\
\hline & 1950 & 6.7 & 13.5 & 52.8 & 20.7 & 6.3 & 2.10 \\
\hline & 1955 & 6.3 & 14.2 & 54.6 & 19.2 & 5.7 & 2.07 \\
\hline & 1960 & 6.5 & 15.4 & 55.3 & 17.4 & 5.4 & 2.03 \\
\hline \multirow[t]{5}{*}{ Romania } & 1950 & 6.3 & 20.9 & 36.5 & 16.1 & 20.2 & 2.48 \\
\hline & 1955 & 8.8 & 21.9 & 38.2 & 14.6 & 16.5 & 2.27 \\
\hline & 1960 & 8.1 & 24.5 & 38.9 & 14.2 & 14.3 & 2.16 \\
\hline & 1965 & 11.7 & 31.1 & 35.6 & 11.7 & 9.9 & 1.91 \\
\hline & 1960 & 4.7 & 26.3 & 53.5 & 12.5 & 3.0 & 1.87 \\
\hline \multirow[t]{6}{*}{ United States } & 1930 & 10.0 & 9.9 & 21.7 & 24.5 & 33.9 & 3.18 \\
\hline & 1935 & 8.3 & 9.9 & 22.5 & 21.6 & 37.7 & 3.14 \\
\hline & 1940 & 9.9 & 11.8 & 27.5 & 17.6 & 33.2 & 2.73 \\
\hline & 1945 & 12.9 & 15.5 & 34.0 & 15.5 & 22.1 & 2.26 \\
\hline & 1950 & 15.6 & 17.9 & 35.4 & 17.4 & 13.7 & 2.03 \\
\hline & 1955 & 16.0 & 18.3 & 35.1 & 19.3 & 11.3 & 1.99 \\
\hline
\end{tabular}


Figure 1 - First birth total cohort fertility rates, selected countries, birth cohorts 1915-1972

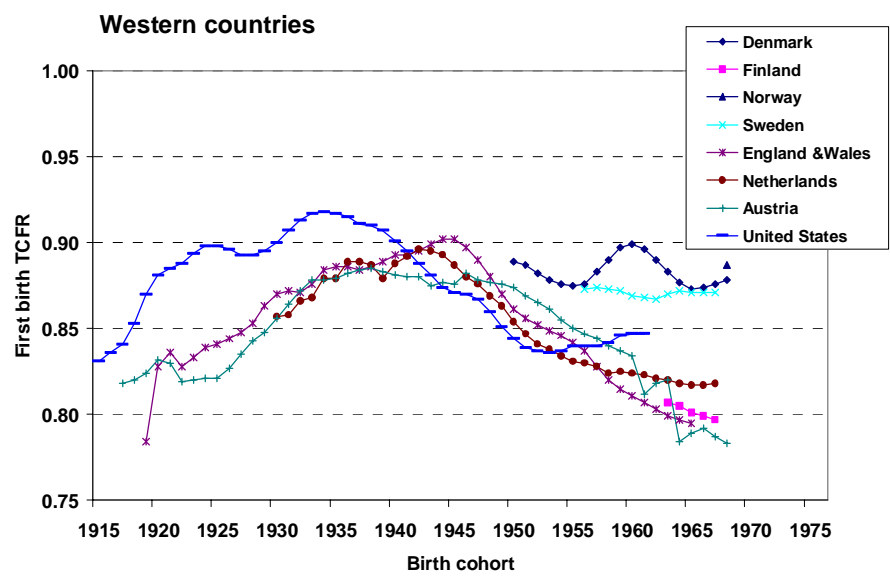

Central and East European countries

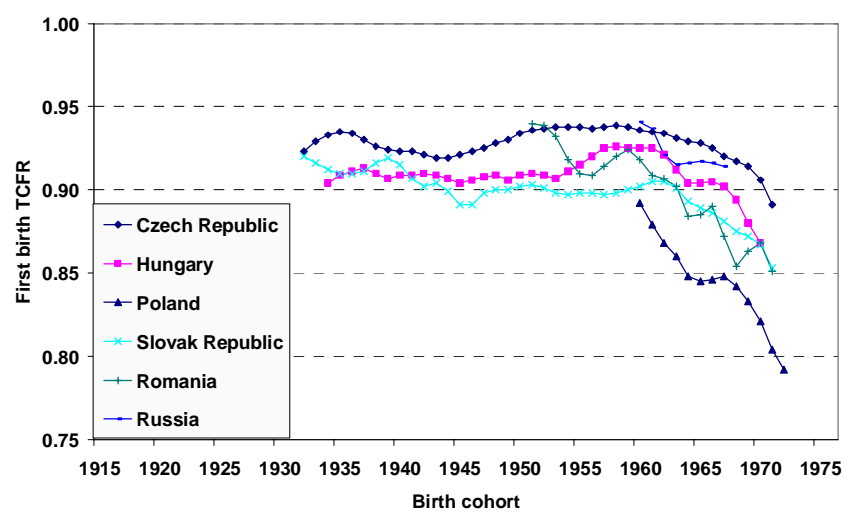

South European countries

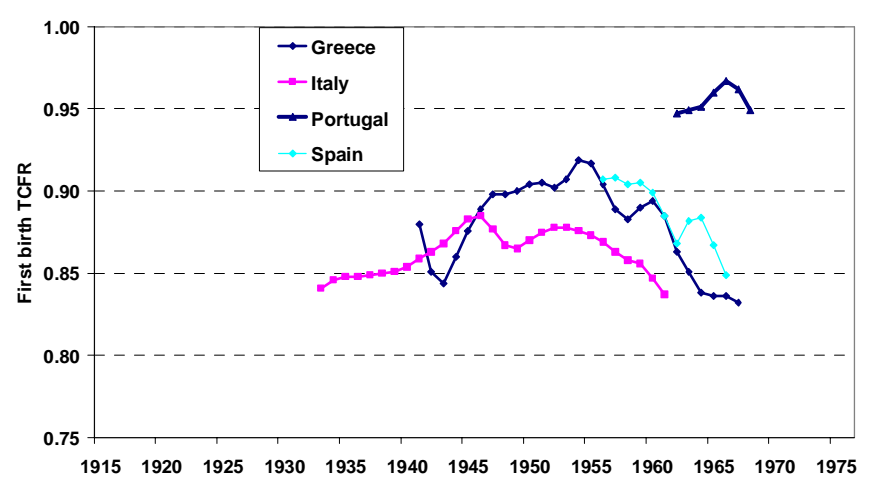

Birth cohort 
Figure 2 - Second birth total cohort fertility rates, selected countries, birth cohorts $1915-1970$
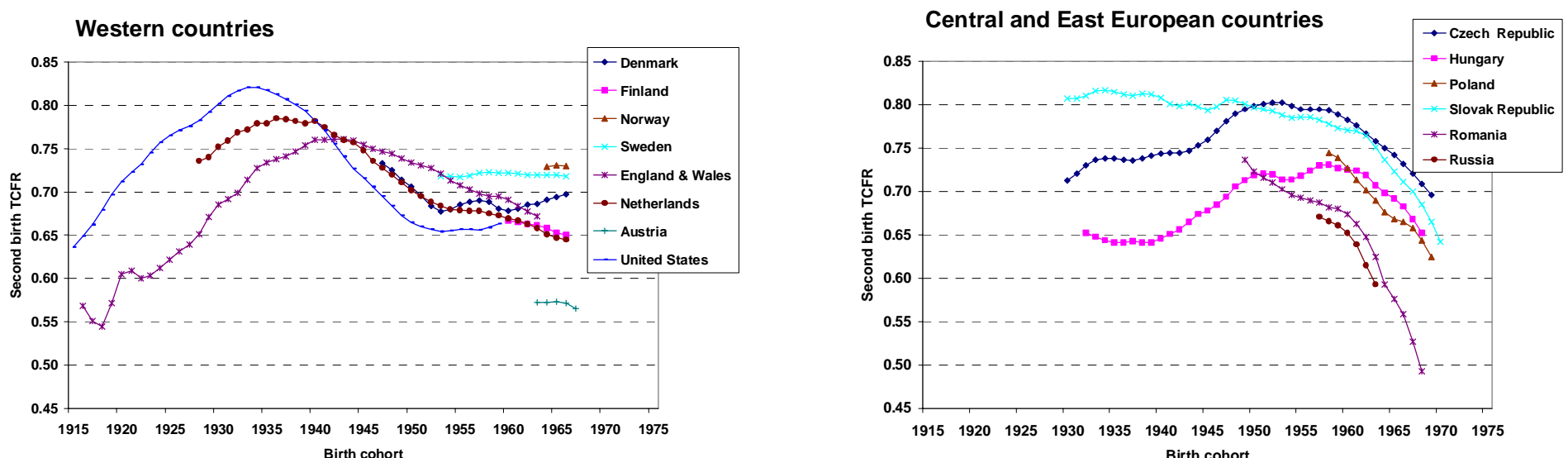

South European countries

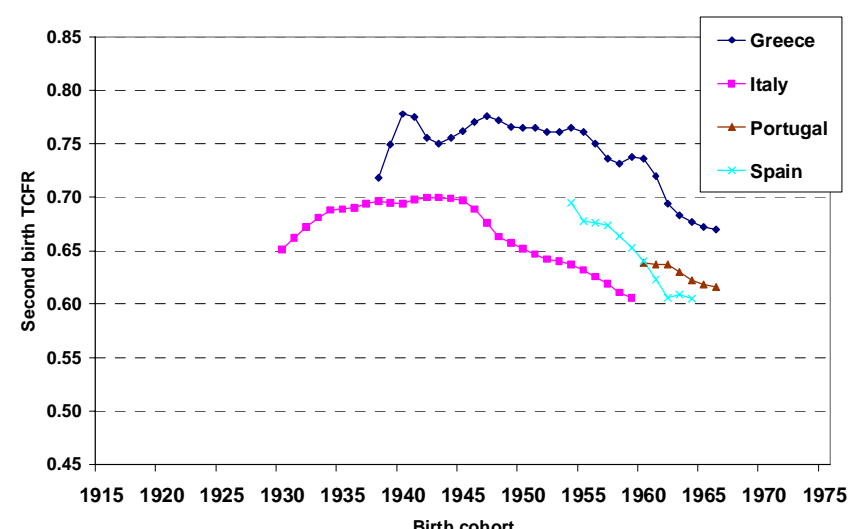

Birth cohort 
Figure 3 - Third birth total cohort fertility rates, selected countries, birth cohorts 1915 - 1966
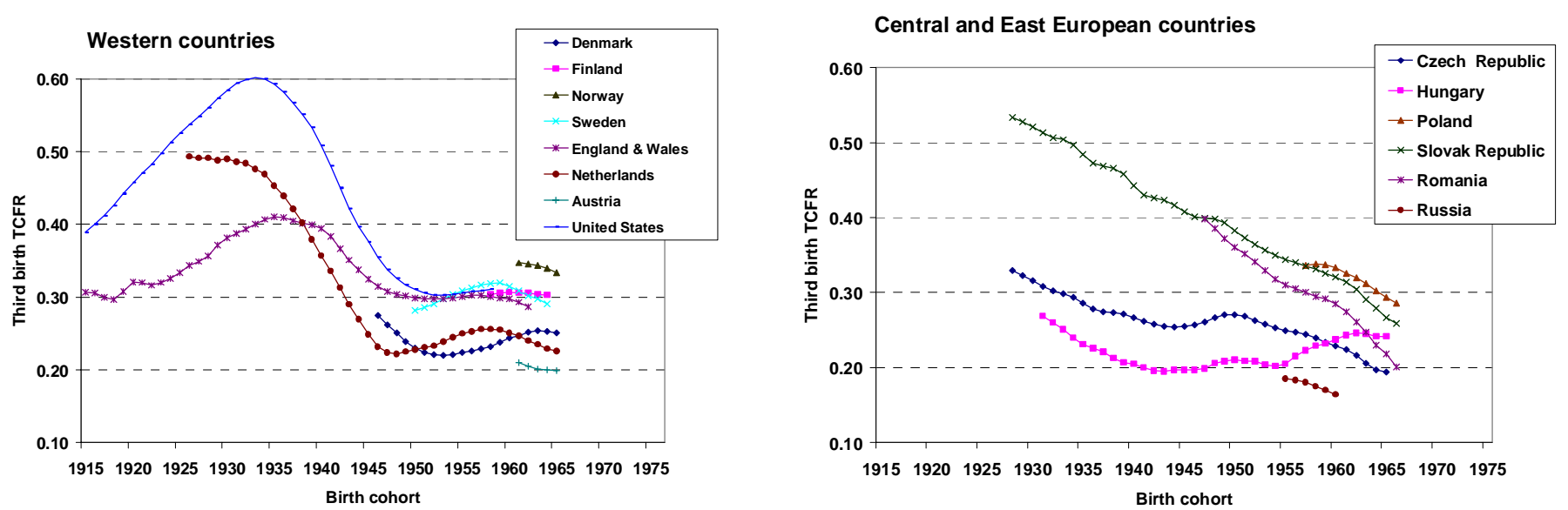

South European countries

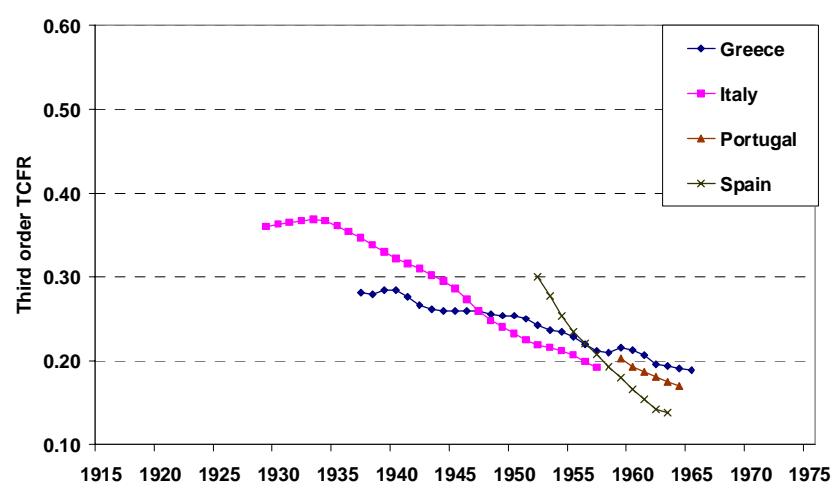

Birth cohort 
Figure 4 - Fourth and higher birth order total cohort fertility rates, selected countries, birth cohorts 1915 - 1963
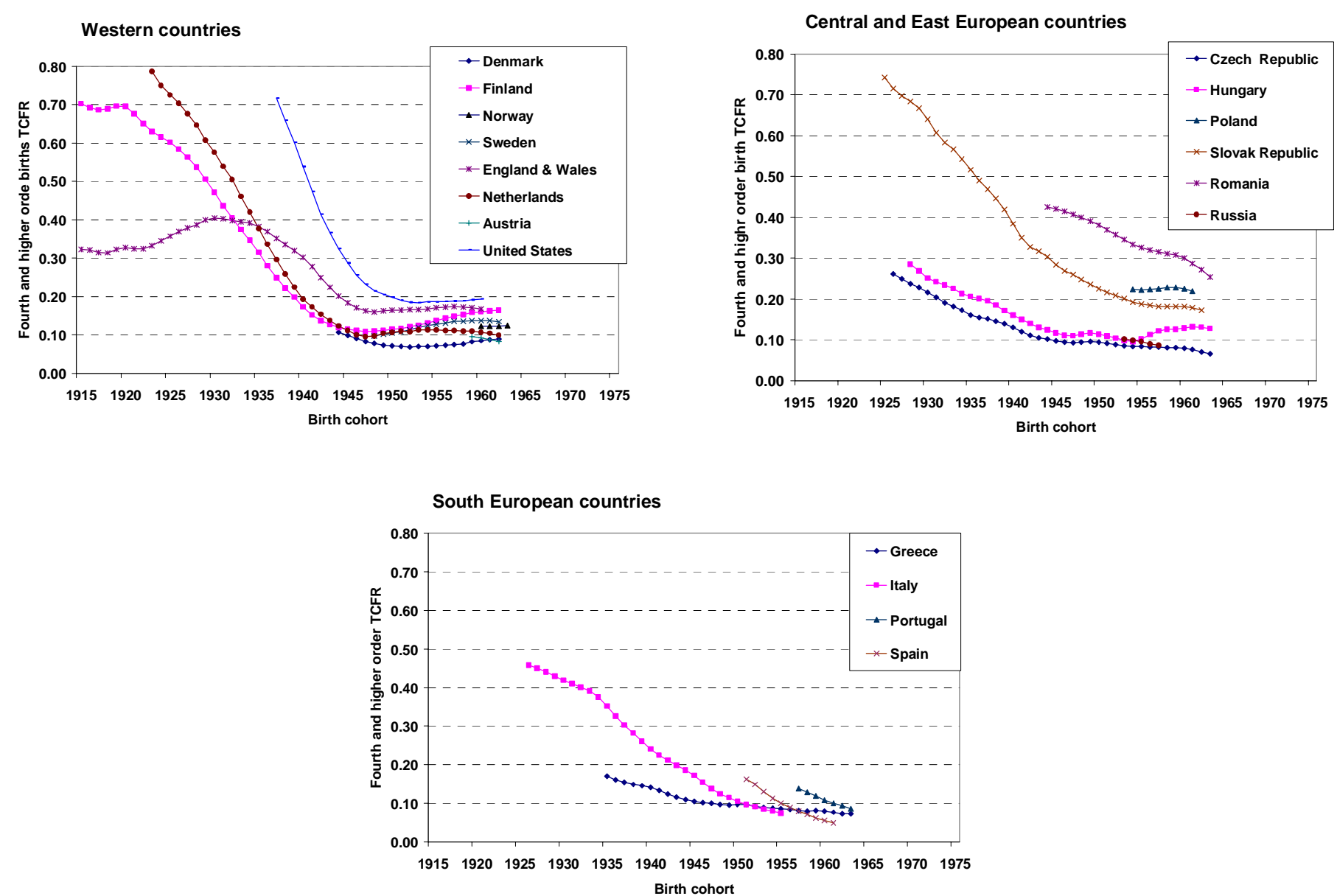
Figure 5 - Cohort mean age for first, second, third, fourth and higher order births, selected countries, birth cohorts 1915-1971
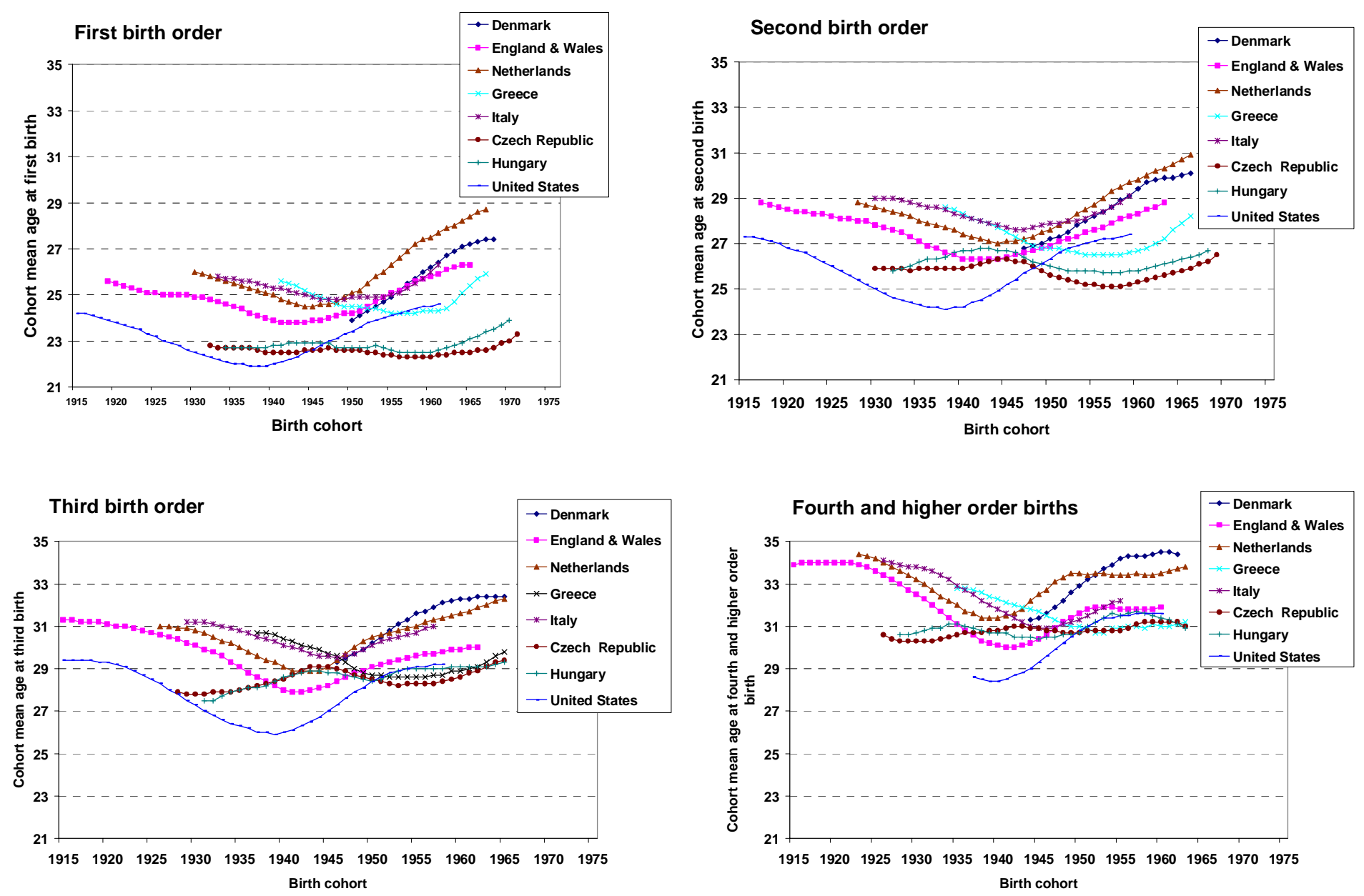
Figure 6 - First, second, third, fourth and higher birth order age-specific fertility rates, birth cohorts 1950, 1960, 1965, 1970, 1975 and 1980, Denmark
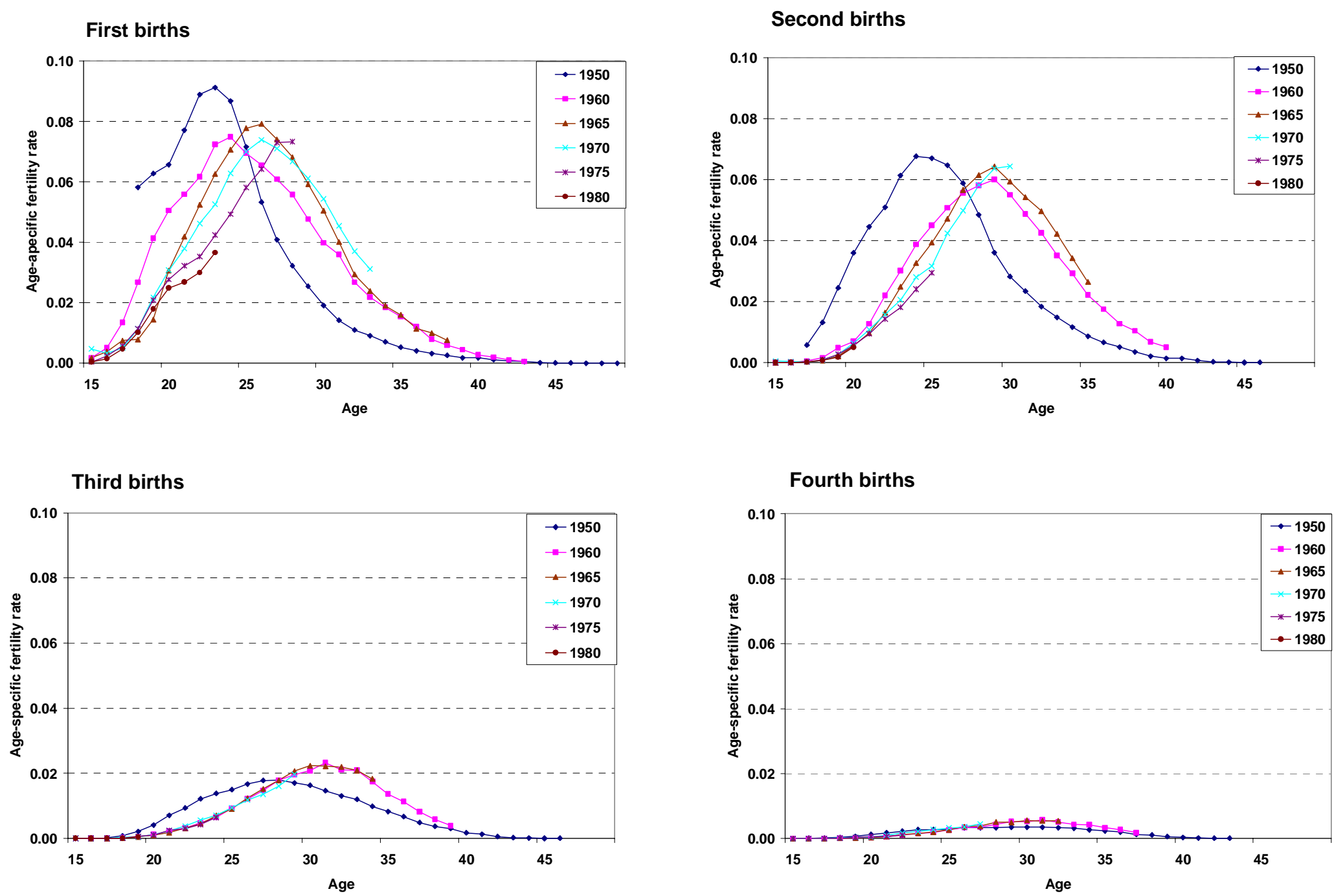
Figure 7.

Total cohort fertility rates by biological birth order, birth cohorts 1926 to 1968
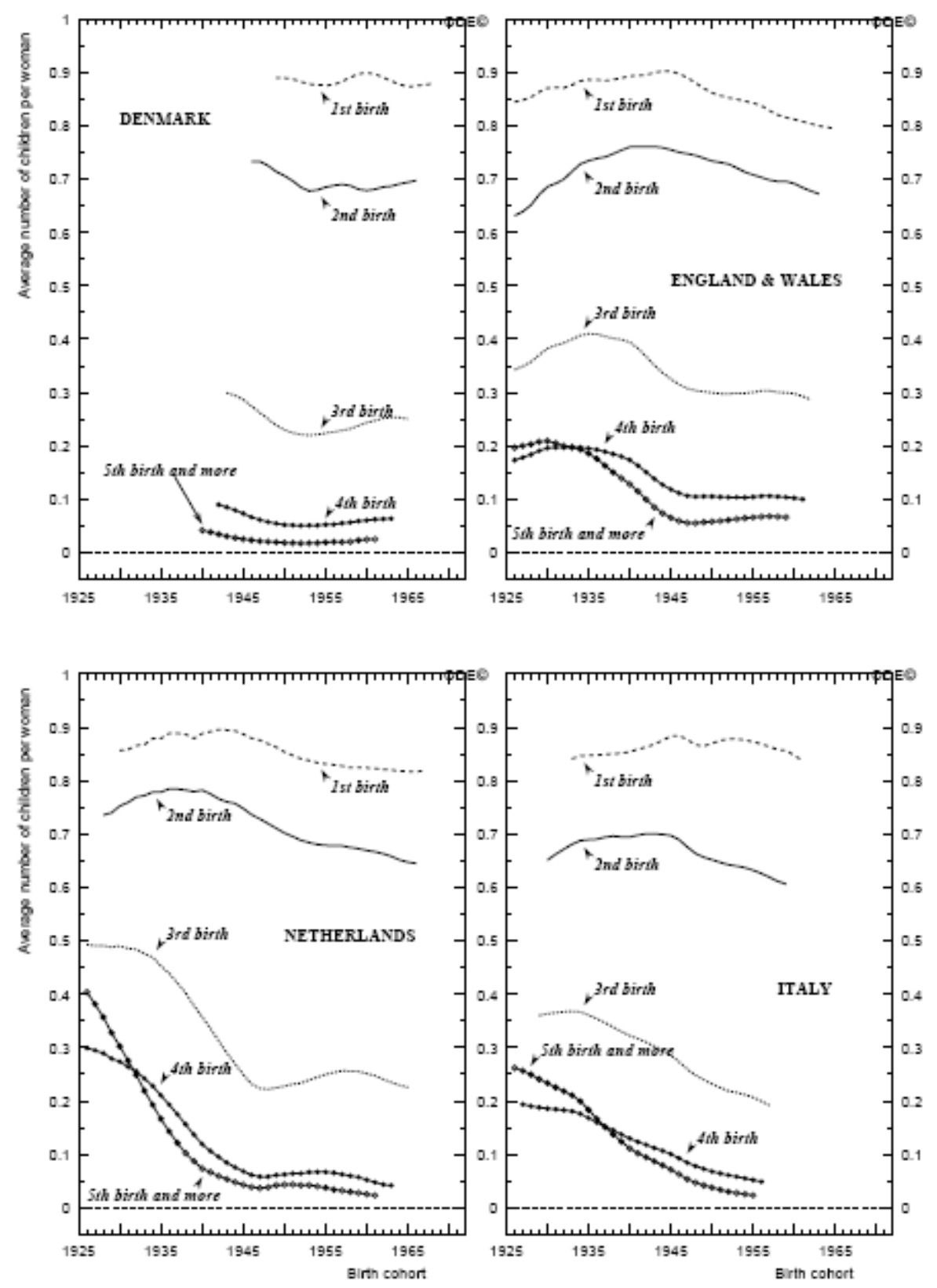
Figure 7.

Total cohort fertility rates by biological birth order, birth cohorts 1926 to 1971
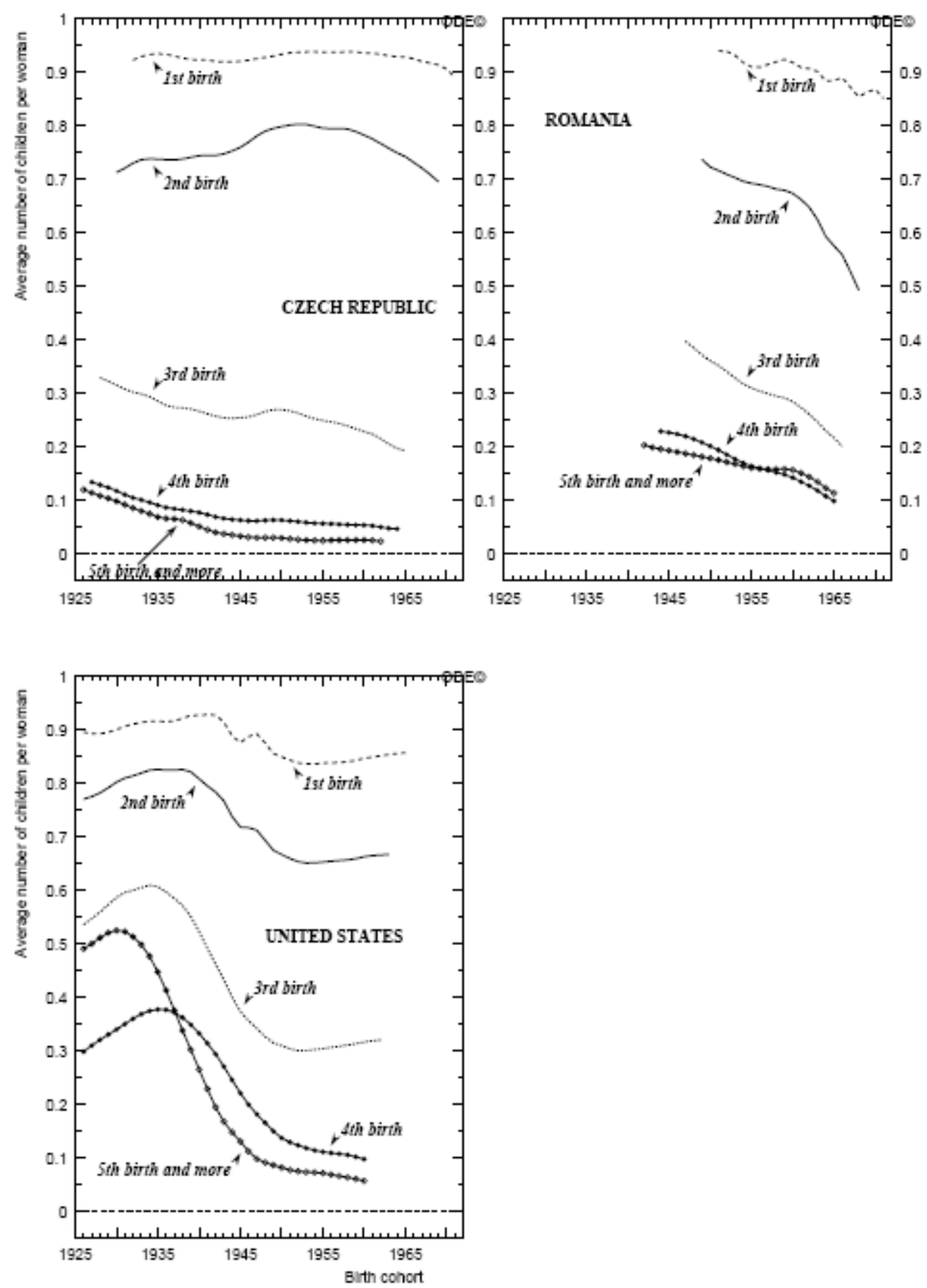
Figure 8.

Parity progression ratios, birth cohorts 1926 to 1972
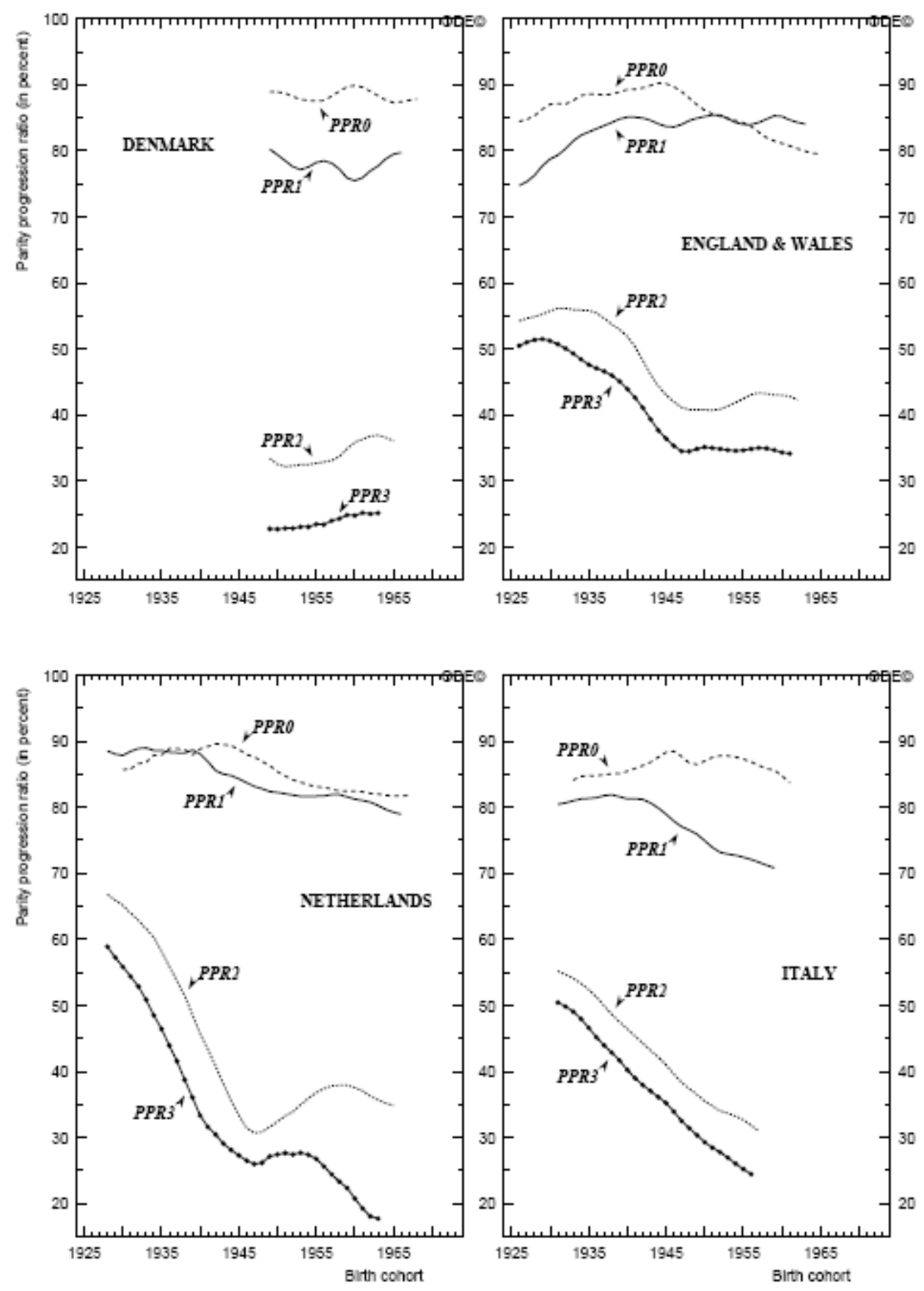
Figure 8.

Parity progression ratios, birth cohorts 1926 to 1972
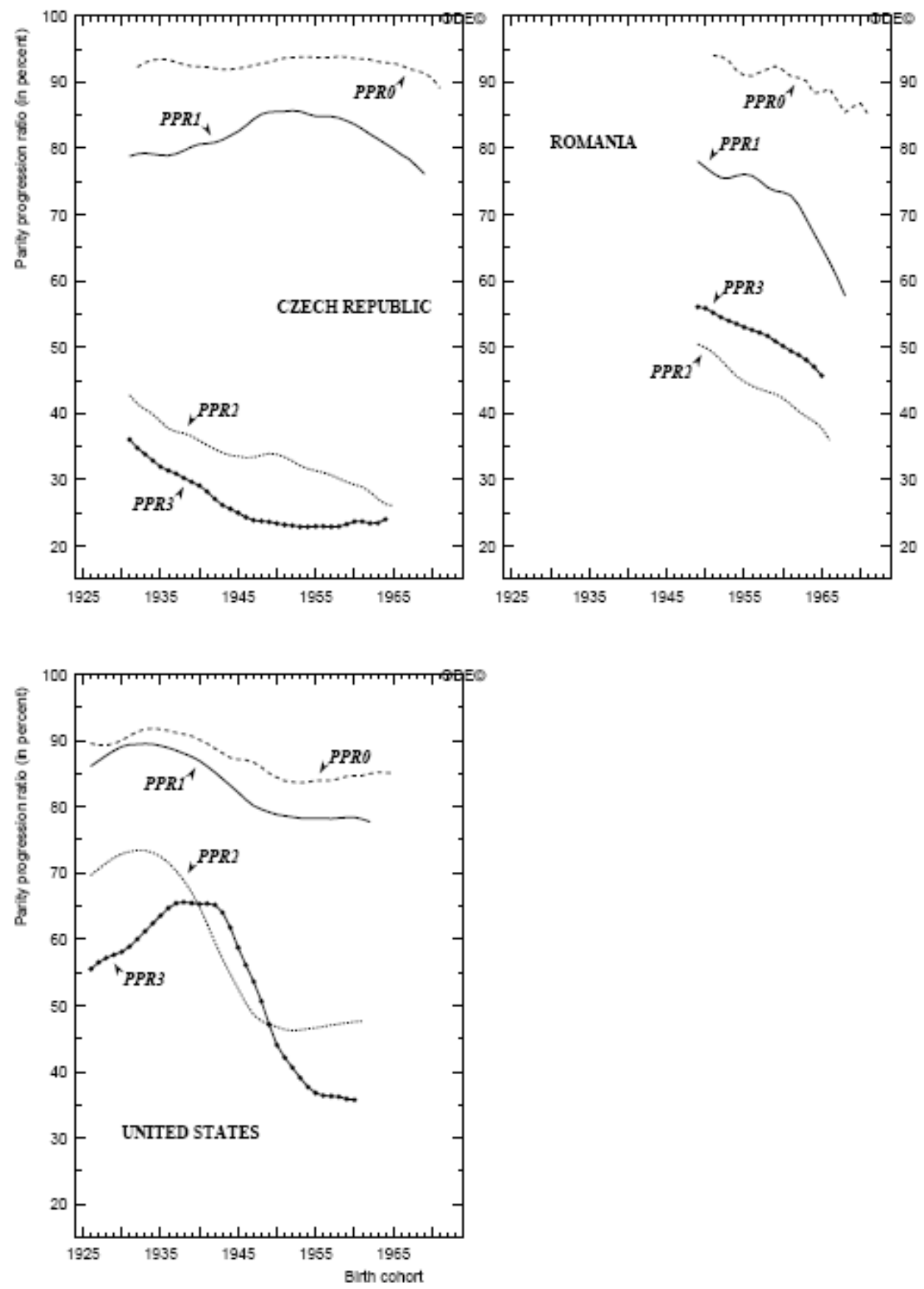
Figure 9.

Parity distribution of completed fertility, birth cohorts 1926 to 1968 (in percent)
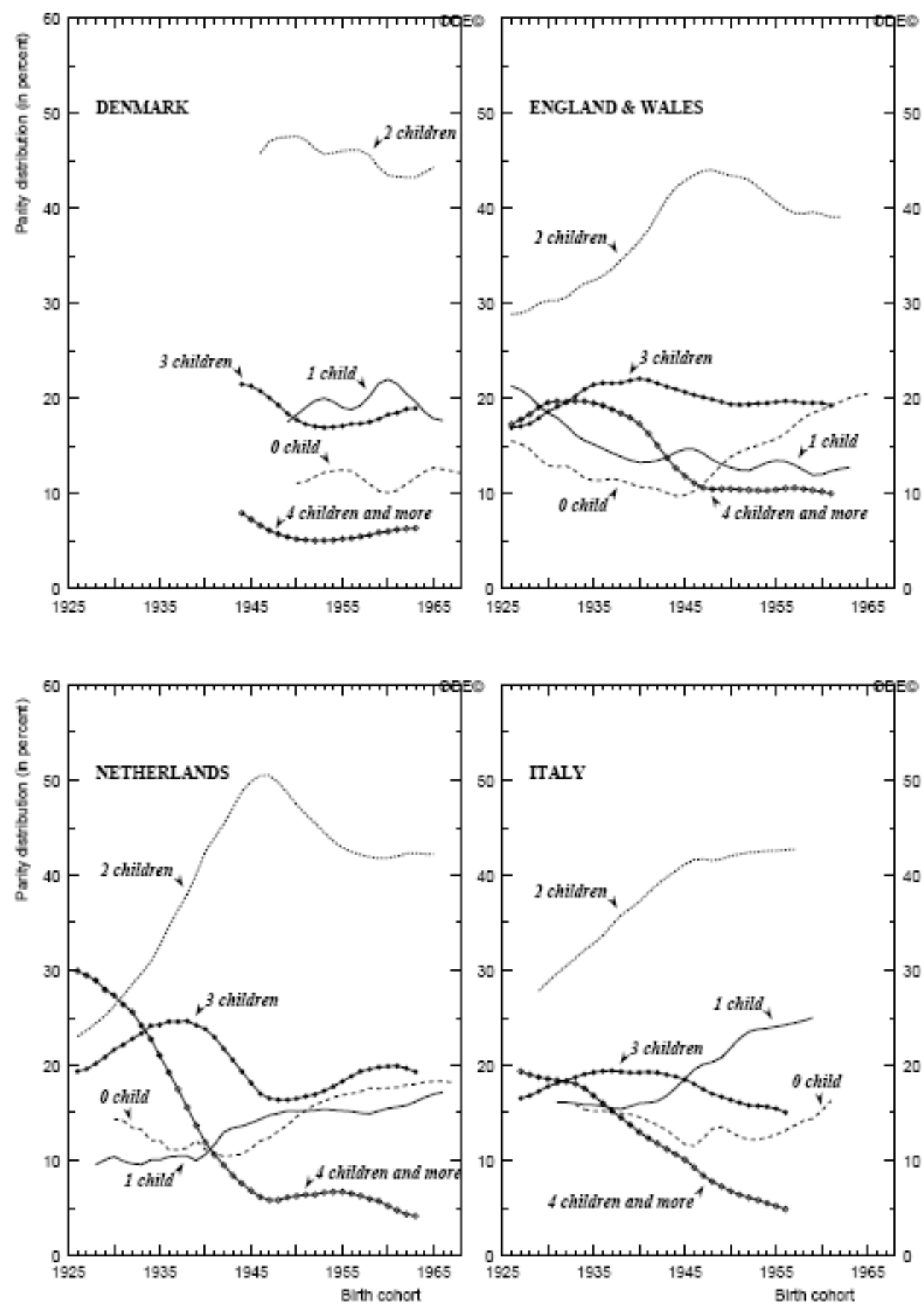
Figure 9.

Parity distribution of completed fertility, birth cohorts 1926 to 1971 (in percent)
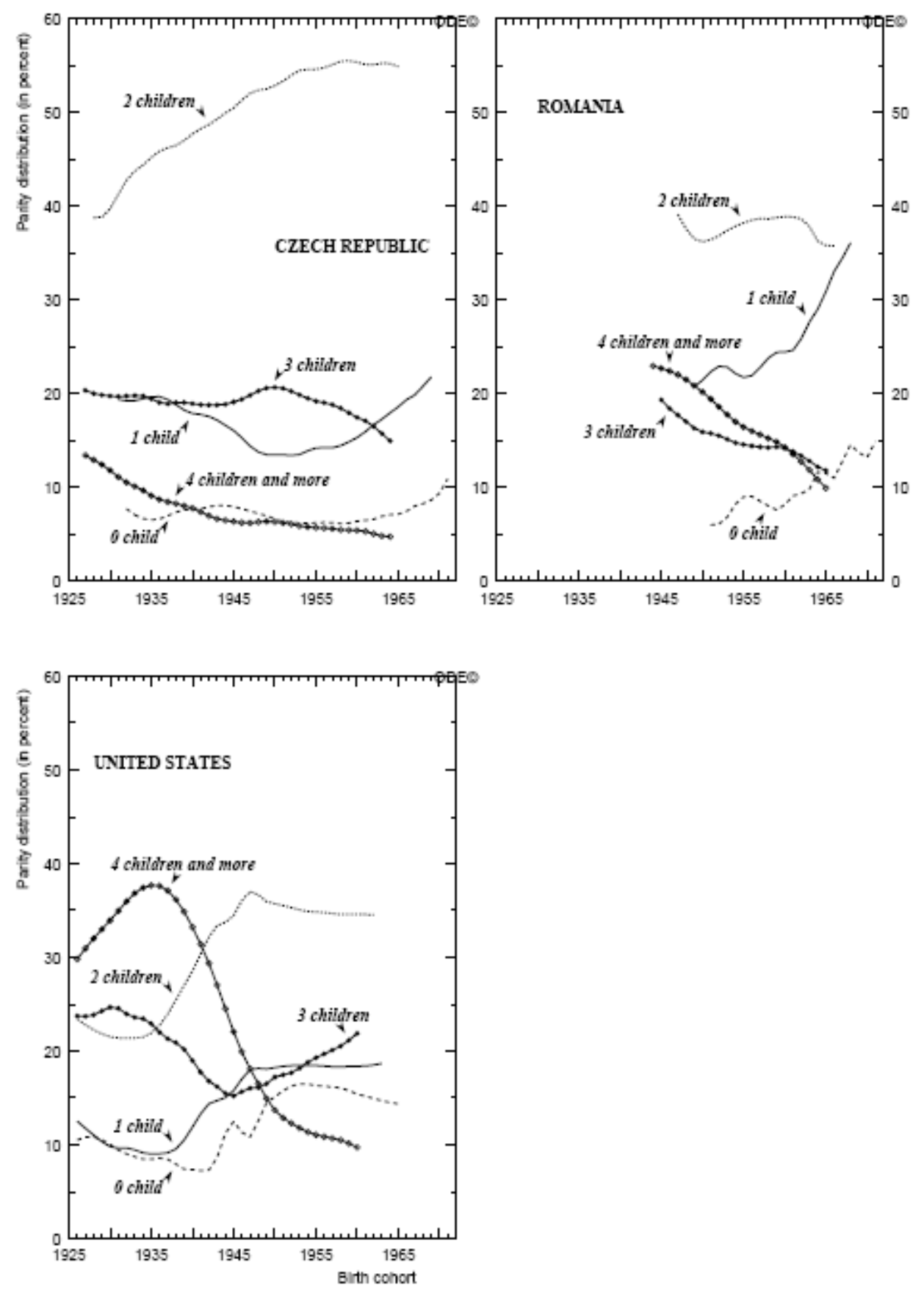
Figure 10 - First, second, third, fourth and higher birth order age-specific fertility rates, birth cohorts 1940, 1950, 1960, 1965, 1970, 1975 and 1980, England \& Wales
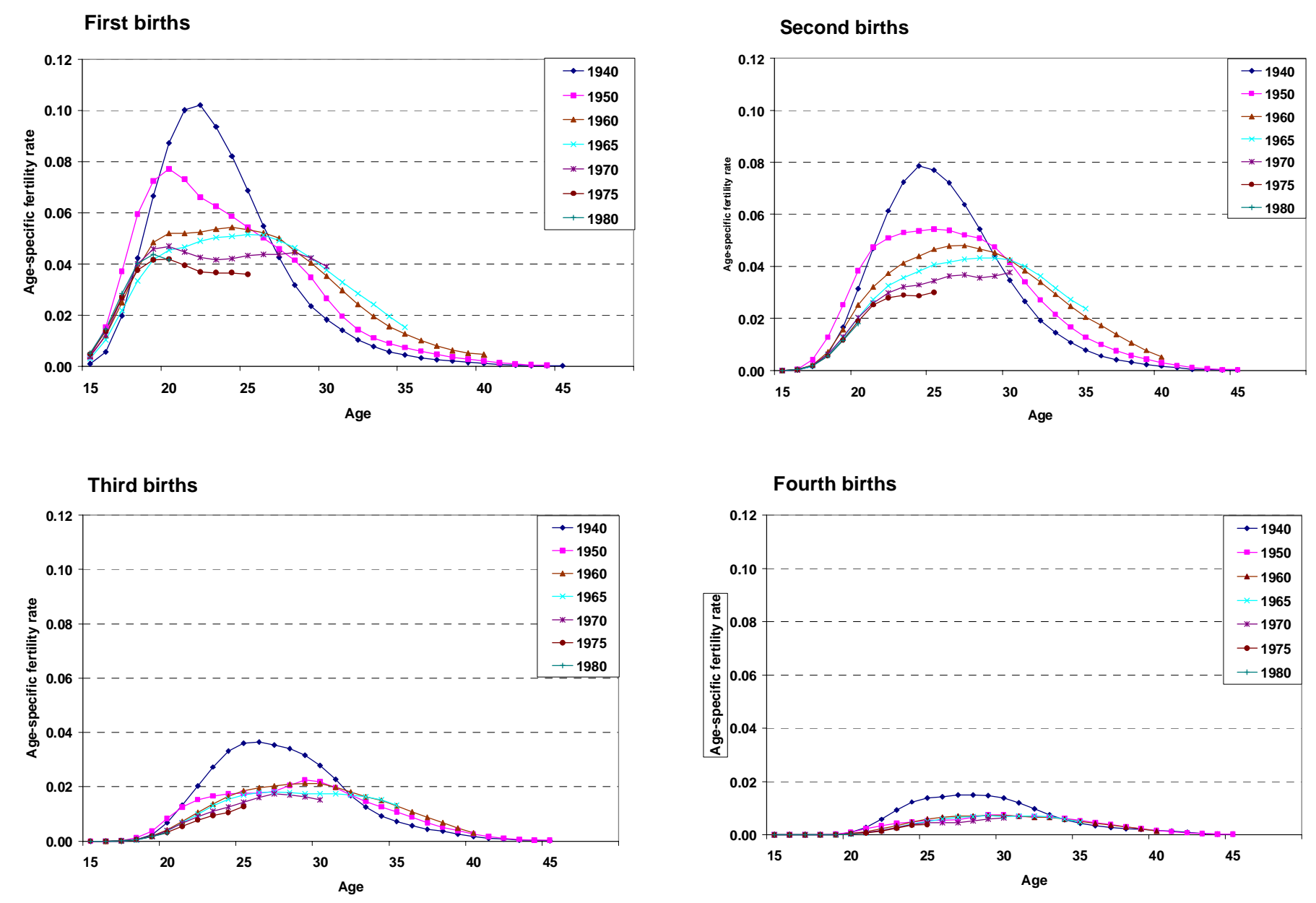
Figure 11 - First, second and third birth order age-specific fertility rates, birth cohorts 1940, 1950, 1960, 1965, 1970, 1975 and 1980, Netherlands
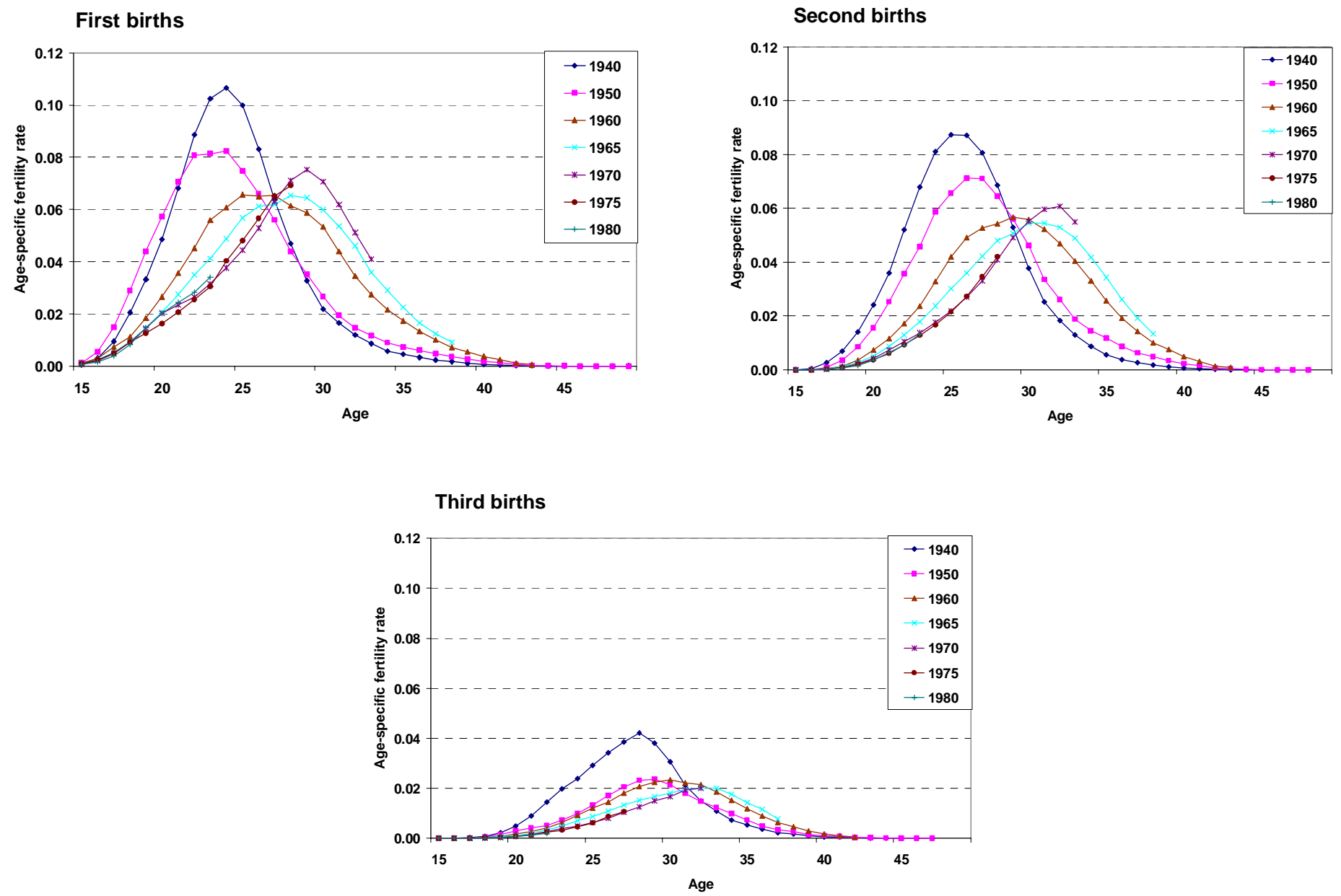
Figure 12 - First, second, third and fourth birth order age-specific fertility rates, birth cohorts 1940, 1950, 1960, 1965, 1970, 1975 and 1980, Italy
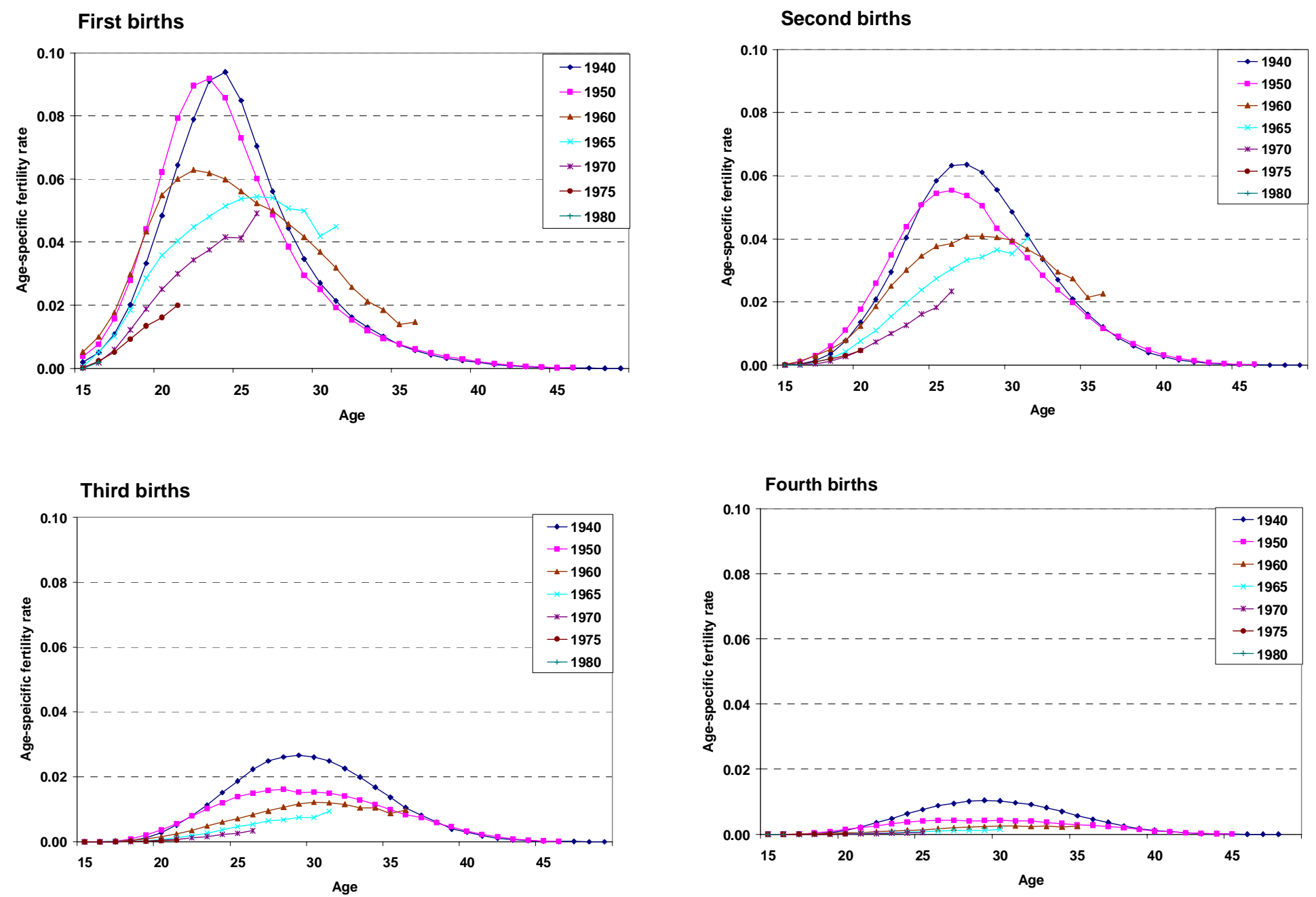
Figure 13 - First, second, third and fourth birth order age-specific fertility rates, birth cohorts 1940, 1950, 1960, 1965, 1970, 1975 and 1980, Czech Republic
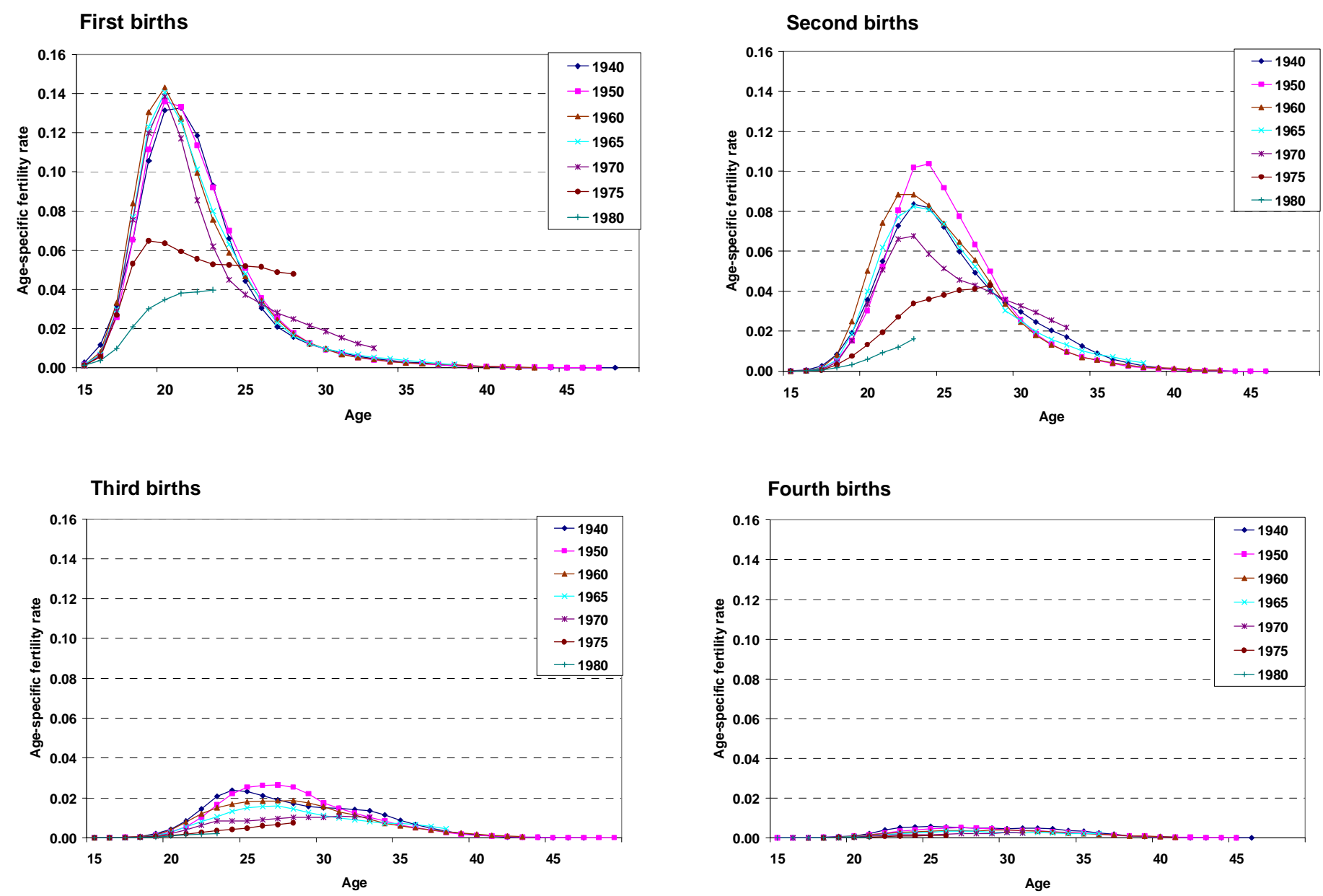
Figure 14 - First, second, third and fourth birth order age-specific fertility rates, birth cohorts 1950, 1960, 1965, 1970, 1975 and 1980, Romania
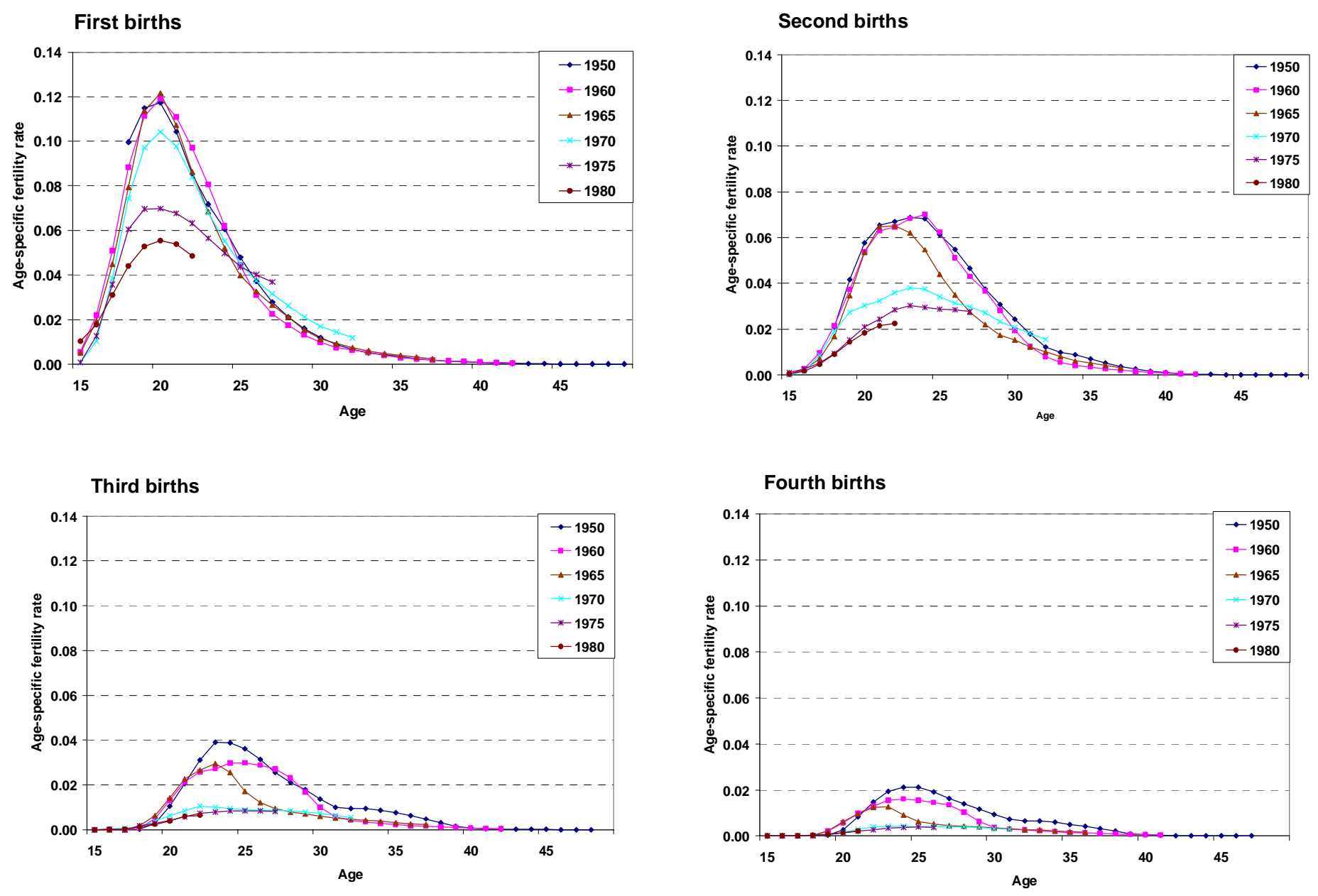
Figure 15 - First, second, third and fourth birth order age-specific fertility rates, birth cohorts 1940, 1950, 1960, 1965, 1970, 1975 and 1980, United States
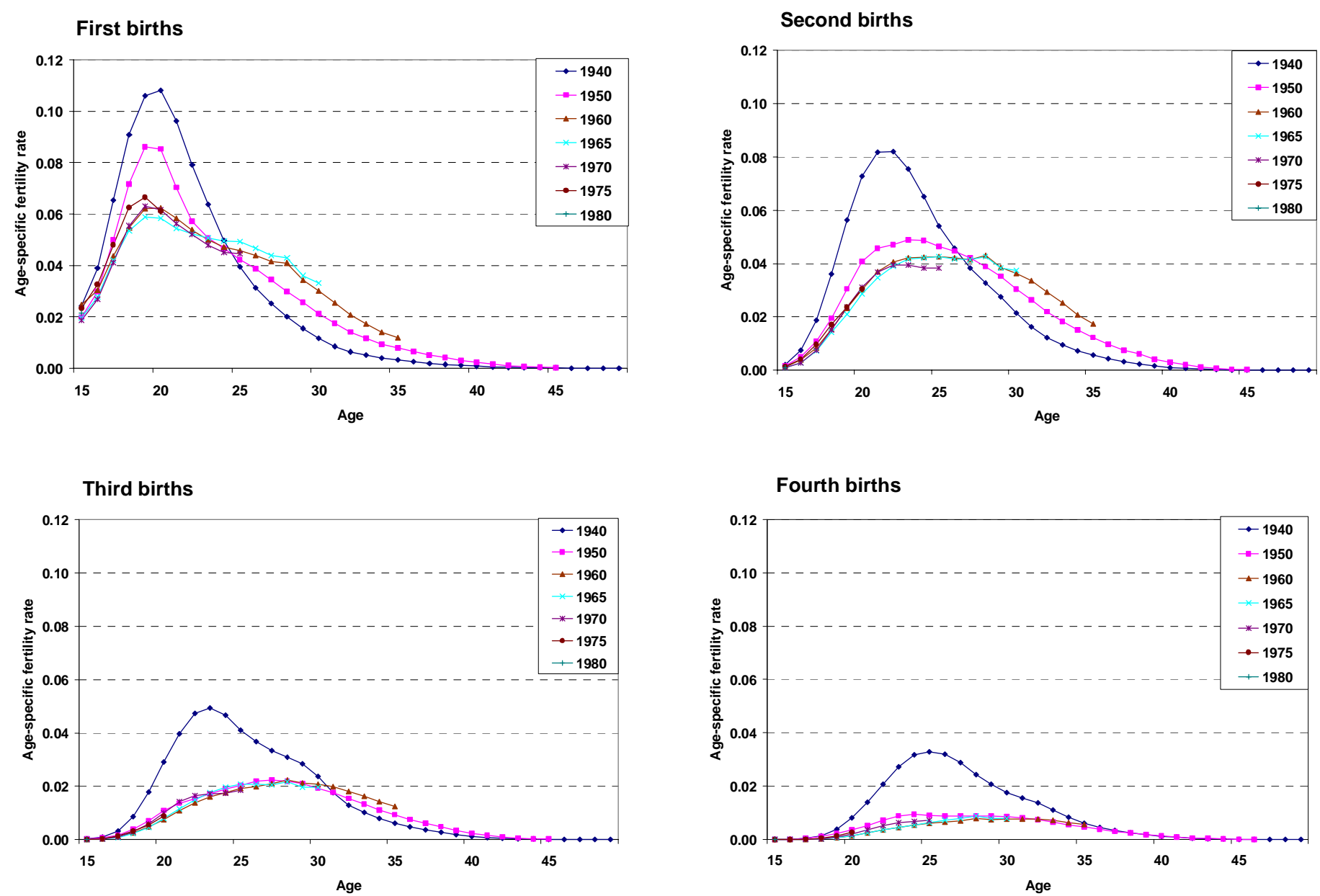